\title{
Relative humidity-dependent viscosities of isoprene-derived secondary organic material and atmospheric implications for isoprene-dominant forests
}

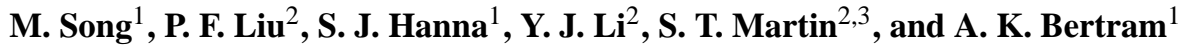 \\ ${ }^{1}$ Department of Chemistry, University of British Columbia, Vancouver, BC V6T 1Z1, Canada \\ ${ }^{2}$ School of Engineering and Applied Sciences, Harvard University, Cambridge, Massachusetts 02138, USA \\ ${ }^{3}$ Department of Earth and Planetary Sciences, Harvard University, Cambridge, Massachusetts 02138, USA
}

Correspondence to: A. K. Bertram (bertram@chem.ubc.ca)

Received: 10 December 2014 - Published in Atmos. Chem. Phys. Discuss.: 14 January 2015

Revised: 10 April 2015 - Accepted: 21 April 2015 - Published: 8 May 2015

\begin{abstract}
Oxidation of isoprene is an important source of secondary organic material (SOM) in atmospheric particles, especially in areas such as the Amazon Basin. Information on the viscosities, diffusion rates, and mixing times within isoprene-derived SOM is needed for accurate predictions of air quality, visibility, and climate. Currently, however, this information is not available. Using a bead-mobility technique and a poke-flow technique combined with fluid simulations, the relative humidity (RH)-dependent viscosities of SOM produced from isoprene photo-oxidation were quantified for $20-60 \mu \mathrm{m}$ particles at $295 \pm 1 \mathrm{~K}$. From 84.5 to $0 \% \mathrm{RH}$, the viscosities for isoprene-derived SOM varied from $\sim 2 \times 10^{-1}$ to $\sim 3 \times 10^{5} \mathrm{Pas}$, implying that isoprenederived SOM ranges from a liquid to a semisolid over this RH range. These viscosities correspond to diffusion coefficients of $\sim 2 \times 10^{-8}$ to $\sim 2 \times 10^{-14} \mathrm{~cm}^{2} \mathrm{~s}^{-1}$ for large organic molecules that follow the Stokes-Einstein relation. Based on the diffusion coefficients, the mixing time of large organic molecules within $200 \mathrm{~nm}$ isoprene-derived SOM particles ranges from approximately $0.1 \mathrm{~h}$ to less than $1 \mathrm{~s}$. To illustrate the atmospheric implications of this study's results, the Amazon Basin is used as a case study for an isoprenedominant forest. Considering the $\mathrm{RH}$ and temperature range observed in the Amazon Basin and with some assumptions about the dominant chemical compositions of SOM particles in the region, it is likely that SOM particles in this area are liquid and reach equilibrium with large gas-phase organic molecules on short time scales, less than or equal to approximately $0.1 \mathrm{~h}$.
\end{abstract}

\section{Introduction}

Vegetation and urban environments emit large quantities of volatile organic compounds (e.g., isoprene, $\alpha$-pinene, and toluene) into the atmosphere (Guenther et al., 1995; Geron et al., 2000; Hakola et al., 2000; Henze et al., 2008). In the atmosphere these volatile organic compounds can be oxidized by $\mathrm{OH}$ radicals, $\mathrm{NO}_{3}$ radicals, and ozone, ultimately contributing to the burden of secondary organic material (SOM) in atmospheric particles (Hallquist et al., 2009). SOM can account for $20-80 \%$ of the mass of atmospheric aerosol particles depending on the location (Zhang et al., 2007; Jimenez et al., 2009). Particles containing SOM are important since they can affect the Earth's energy budget directly by scattering and/or absorbing solar radiation and indirectly by serving as nuclei for cloud formation (IPCC, 2013). Moreover, they can influence air quality and human health (Jang et al., 2006; Baltensperger et al., 2008).

Recently, the phase (i.e., solid vs. semisolid vs. liquid), viscosity, and molecular diffusion within SOM have been an area of focus in the atmospheric community. This is because knowledge of these physical properties is needed for modeling the environmental impacts of SOM particles (Koop et al., 2011; Pfrang et al., 2011; Riipinen et al., 2011, 2012; Shiraiwa et al., 2011, 2013; Perraud et al., 2012; Shiraiwa and Seinfeld, 2012; Zelenyuk et al., 2012; Zhou et al., 2013). For example, when SOM particles are solid they may participate in heterogeneous ice nucleation in the atmosphere (Murray et al., 2010; Wang et al., 2012). As another example, researchers have shown that predictions of ultrafine par- 
ticle number concentrations and size distributions depend on the diffusion rates of organics within SOM particles (Riipinen et al., 2011). In addition, researchers have shown that predictions of total SOM mass concentrations in urban environments are dependent on the diffusion rates of organics in SOM (Shiraiwa and Seinfeld, 2012). Moreover, it has been demonstrated that long-range transport of polycyclic aromatic hydrocarbons can depend on diffusion rates in a particle (Zelenyuk et al., 2012; Zhou et al., 2013). Furthermore, when viscosities are high in particles containing SOM material, they can inhibit the efflorescence of crystalline salts by affecting nucleation rates and/or crystal growth rates (Bodsworth et al., 2010; Song et al., 2013).

The phase, viscosity, and molecular diffusion rate within SOM are closely related properties (Koop et al., 2011; Shiraiwa et al., 2011). An amorphous solid is defined as a material having a viscosity greater than $10^{12} \mathrm{Pas}$, a semisolid is defined as a material having a viscosity between $10^{2}$ and $10^{12} \mathrm{~Pa} \mathrm{~s}$, and a liquid is defined as a material having a viscosity less than $10^{2} \mathrm{~Pa}$. Viscosities and molecular diffusion rates are related with an increase in viscosity leading to a decrease in molecular diffusion rates. For the transport of large organic molecules in SOM, molecular diffusion rates may be related to viscosity through the Stokes-Einstein equation (Koop et al., 2011).

An important biogenic source of SOM is the oxidation of $\alpha$-pinene. Recently, there has been a significant amount of research on the phase, viscosity, and diffusion rates in SOM generated from the oxidation of $\alpha$-pinene (Virtanen et al., 2010; Cappa and Wilson, 2011; Perraud et al., 2012; Saukko et al., 2012; Abramson et al., 2013; Renbaum-Wolff et al., 2013a; Robinson et al., 2013; Kidd et al., 2014; Pajunoja et al., 2014; Wang et al., 2014). These different studies have shown or inferred that viscosities can be higher than $10^{2} \mathrm{~Pa}$ and diffusion rates of large organic molecules can be slower than $\sim 10^{-10} \mathrm{~cm}^{2} \mathrm{~s}^{-1}$ in SOM particles generated from $\alpha$ pinene oxidation at low relative humidity $(\mathrm{RH})$, although there are still disagreements in the exact values of the viscosities and diffusion rates in these particles.

Another important biogenic source of SOM in the atmosphere is photo-oxidation of isoprene. In the southeast USA during the summer months in 2006 and 2011, up to $40 \%$ of measured $\mathrm{PM}_{2.5}$ organic carbon was attributed to isoprenederived SOM (Offenberg et al., 2011; Budisulistiorini et al., 2013). In central East China during the Mount Tai Experiment 2006 campaign (MTX2006) in early summer, isoprenederived SOM was 7 times greater than monoterpene-derived SOM (Fu et al., 2010). In the maritime tropical forest in Danum Valley, Borneo, Malaysia, during summer 2008, isoprene-derived SOM accounted for as much as half of the mass concentrations of total submicron organic particles (Robinson et al., 2011). In the wet season of 2008 during the Amazonian Aerosol Characterization Experiment (AMAZE08), mass spectra of submicron organic particles were consistent with reference spectra of SOM generated from isoprene and terpene oxidation (Chen et al., 2009; Pöschl et al., 2010; Pöhlker et al., 2012). Speciation studies using chromatography have also illustrated that isoprene oxidation is a major source of SOM in the Amazon Basin during clean conditions (Claeys et al., 2004). A recent study using positive matrix factorization of aerosol mass spectra has also shown that isoprene-derived SOM is an important component of submicron particles in the Amazon Basin (Chen et al., 2015).

Although isoprene is a major source of SOM in some regions of the atmosphere, such as the Amazon Basin, there have only been a few studies that have investigated the phase (i.e., liquid vs. semisolid or solid) of isoprene-derived SOM (Saukko et al., 2012; Bateman et al., 2014). In addition, there has only been one study that has addressed the viscosity in isoprene-derived SOM (Bateman et al., 2014). In the current study we focus on the viscosities and diffusion rates of organic molecules as a function of $\mathrm{RH}$ in SOM generated from photo-oxidation of isoprene. Studies as a function of $\mathrm{RH}$ are needed since as the RH varies in the atmosphere SOM particles can take up water, which can change the viscosities and diffusion rates in the particles (Koop et al., 2011; Shiraiwa et al., 2011; Power et al., 2013; Renbaum-Wolff et al., 2013a; Shiraiwa et al., 2013; Zhou et al., 2013). Our approach involves measuring the viscosity of isoprene-derived SOM and then relating the viscosity to diffusion rates of organic molecules in the SOM using the Stokes-Einstein relationship. Based on their laboratory experiments studying the $\mathrm{RH}$ dependence of particle rebound for different types of SOM, the results of Bateman et al. (2014) appear to explain why organic particles present in terpene-dominant conditions of a boreal forest at low $\mathrm{RH}$ are solid whereas organic particles for isoprene-dominant tropical forests at high $\mathrm{RH}$ are liquid. In addition to determining viscosities and diffusion rates, we also use the new data to assess whether SOM in the Amazon Basin during clean conditions will rapidly reach equilibrium with large gas-phase organic molecules under $\mathrm{RH}$ values typically encountered in the region.

\section{Methods}

Primary SOM particles having diameters $<5 \mu \mathrm{m}$ were produced by photo-oxidation of isoprene compounds in an oxidation flow reactor (OFR) and then collected onto hydrophobic substrates (Sect. 2.1). The primary particles were collected (Sect. 2.1) and converted into larger particles having diameters between 20 and $60 \mu \mathrm{m}$ (Sect. 2.2). The viscosities of the supermicron-sized particles were determined at $295 \pm 1 \mathrm{~K}$ both with the bead-mobility technique (Sect. 2.3) and the poke-flow technique (Sect. 2.4). 
Table 1. Experimental conditions for production of isoprene-derived SOM particles using the oxidation flow reactor. Particles were deposited on substrates using an electrostatic precipitator. SOMs from isoprene samples 1, 2, and 3 were collected on Teflon substrates for the beadmobility experiments, and SOMs from isoprene samples 4, 5, and 6 were collected on salinized substrates for the poke-flow experiments.

\begin{tabular}{lrrrrr}
\hline $\begin{array}{l}\text { SOM } \\
\text { sample }\end{array}$ & $\begin{array}{r}\text { Isoprene } \\
\text { conc. } \\
(\mathrm{ppm})\end{array}$ & $\begin{array}{r}\text { Ozone } \\
\text { conc. } \\
(\mathrm{ppm})\end{array}$ & $\begin{array}{r}\text { SOM mass } \\
\text { conc. } \\
\left(\mu \mathrm{g} \mathrm{m}^{-3}\right)\end{array}$ & $\begin{array}{r}\text { OFR } \\
\text { flow rate } \\
\left(\mathrm{L} \mathrm{m}^{-1}\right)\end{array}$ & $\begin{array}{r}\text { Collection } \\
\text { time } \\
(\text { day })\end{array}$ \\
\hline Isoprene 1 & $7 \pm 2$ & $10 \pm 2$ & $300-400$ & $9.5 \pm 0.1$ & 2 \\
Isoprene 2 & $7 \pm 2$ & $13 \pm 2$ & $500-1000$ & $7.0 \pm 0.1$ & 7 \\
Isoprene 3 & $7 \pm 2$ & $13 \pm 2$ & $500-1000$ & $7.0 \pm 0.1$ & 7 \\
Isoprene 4 & $4 \pm 2$ & $10 \pm 2$ & $100-200$ & $9.5 \pm 0.1$ & 3 \\
Isoprene 5 & $7 \pm 2$ & $13 \pm 2$ & $500-1000$ & $7.0 \pm 0.1$ & 4 \\
Isoprene 6 & $7 \pm 2$ & $13 \pm 2$ & $500-1000$ & $7.0 \pm 0.1$ & 4 \\
\hline
\end{tabular}

\subsection{Production of particles consisting of secondary organic material on hydrophobic surfaces}

Particles consisting of SOM were produced by the photooxidation of isoprene compounds in an OFR (Kang et al., 2007). The procedures were described in detail in Liu et al. (2013, 2015). Table 1 lists the experimental conditions used in this study. The volume of the OFR was $13.3 \mathrm{~L}$ and the OFR was operated at a flow of 7.0 and $9.5 \mathrm{~L} \mathrm{~min}^{-1}$, resulting in residence times of 114 and $84 \mathrm{~s}$, respectively. The temperature used in the OFR experiments was $293 \pm 2 \mathrm{~K}$. $\mathrm{RH}$ in the reactor was maintained at $13 \pm 3 \%$ during particle generation. For injection of isoprene vapor into the OFR, $2 \mathrm{~mL}$ of liquid isoprene (Sigma-Aldrich, 99\%) was placed in an upright Teflon tube with the lower end sealed and the upper end connected to a T-fitting. The fitting was flushed by purified air, thereby producing a gas flow containing isoprene vapor. The injected isoprene concentration was 4-7 ppm. Ozone was produced external to the flow reactor by irradiating pure air with the ultraviolet emission from a mercury-vapor lamp $(\lambda=185 \mathrm{~nm})$. The injected ozone concentration was $10-13 \mathrm{ppm}$. Hydroxyl radicals were produced inside the OFR by the following photochemical reactions:

$\mathrm{O}_{3}+h v \rightarrow \mathrm{O}_{2}+\mathrm{O}\left({ }^{1} \mathrm{D}\right)$

$\mathrm{O}\left({ }^{1} \mathrm{D}\right)+\mathrm{H}_{2} \mathrm{O} \rightarrow 2 \mathrm{OH}$.

Although the $\mathrm{OH}$ concentration was not measured in the OFR in this study, an $\mathrm{OH}$ concentration in the OFR in the range of $2 \times 10^{8}$ to $2 \times 10^{10}$ molec $\mathrm{cm}^{-3}$ was expected based on previous experiments under similar conditions (Lambe et al., 2011a). This $\mathrm{OH}$ concentration corresponds to a lifetime of isoprene between 0.5 and $50 \mathrm{~s}$. For comparison, the $\mathrm{O}_{3}$ concentrations used in these experiments correspond to a lifetime of isoprene of approximately $3.6 \mathrm{~min}$. The $\mathrm{OH}$ concentration in the OFR was adjusted by changing the power of the UV lamps as described in Lambe et al. (2011a). For the experiments in this study, the lamp power was always full; therefore, the $\mathrm{OH}$ concentration in this study should have been close to $2 \times 10^{10} \mathrm{molec}^{-3}$, and the $\mathrm{OH}$ pathway should have dominated the oxidation of isoprene.

Based on the flow tube residence times and the expected $\mathrm{OH}$ concentrations, $\mathrm{OH}$ exposures were expected to be in the range of $2.0 \times 10^{10}$ to $1.8 \times 10^{12} \mathrm{molec} \mathrm{cm}^{-3}$. When one assumes an average atmospheric $\mathrm{OH}$ concentration of $1.5 \times 10^{6} \mathrm{molec}^{-3}$, this range of exposures is equivalent to $\sim 0.15$ to $\sim 15$ days of atmospheric oxidation by $\mathrm{OH}$ (Lambe et al., 2011a).

The concentration of the major oxidants $\left(\mathrm{O}_{3}, \mathrm{OH}\right.$, and $\mathrm{HO}_{2}$ ) in the OFR is higher than in environmental chambers or the atmosphere, but the ratios of $\mathrm{O}_{3}$ to $\mathrm{OH}$ and $\mathrm{OH}$ to $\mathrm{HO}_{2}$ are similar to those encountered in the atmosphere and in environmental chambers. As a result, the OFR is used to simulate oxidation processes in the atmosphere and environmental chambers. Recent measurements with an aerosol mass spectrometer have shown that the composition of isoprenederived SOM produced with an OFR is the same, within the uncertainty of the measurements, as isoprene-derived SOM produced with an environmental chamber (Lambe et al., 2015).

In the current study, the $\mathrm{O}: \mathrm{C}$ ratio of the isoprene-derived SOM was not measured. However, in previous studies using the Harvard OFR, an $\mathrm{O}: \mathrm{C}$ value of 0.82 for isoprenederived SOM was measured using lower concentrations of isoprene $(700 \mathrm{ppb})$. In these previous studies the $\mathrm{O}: \mathrm{C}$ was calculated using the explicit approach described by Chen et al. (2011). In addition, the average $\mathrm{O}: \mathrm{C}$ values of isoprenederived SOM was found to be 0.64 to 0.79 by Chhabra et al. (2010) and 0.75 to 0.88 by Chen et al. (2011) in environmental chamber studies and 0.64 to 1.1 by Lambe et al. $(2011 b, 2015)$ in explicit studies using a similar OFR. The O:C values reported here for Chhabra et al. (2010) and Lambe et al. (2011b) have been scaled up by a factor of 1.27 as suggested by Canagaratna et al. (2015). Based on this information, we estimate that the $\mathrm{O}: \mathrm{C}$ of isoprene-derived SOM in the current experiments was in the range of 0.64 to 1.1 .

Particles consisting of SOM produced from the photooxidation of isoprene were collected onto hydrophobic 
substrates using an electrostatic precipitator (TSI 3089, USA) connected to the outflow of the OFR. Shown in Fig. 1a is an example of an image of particles collected on a hydrophobic substrate using this process. Teflon substrates were used as the hydrophobic substrates for the bead-mobility experiments (see Sect. 2.3). Glass slides coated with trichloro $(1 H, 1 H, 2 H, 2 H$-perfluorooctyl)silane (Sigma-Aldrich) were used as hydrophobic substrates for the poke-flow experiments (see Sect. 2.4). The method of coating glass slides with a silane is described in Knopf (2003).

\subsection{Production of 20-60 $\mu \mathrm{m}$ particles}

Particles of $20-60 \mu \mathrm{m}$ were required to perform beadmobility and poke-flow experiments (see Sect. 2.3 and 2.4). To make the appropriate particle sizes for these experiments, the hydrophobic substrates containing particles collected from the OFR were placed in a RH-controlled flow cell coupled to a reflectance microscope (Zeiss Axiotech, magnification of 50 times) (Pant et al., 2006; Bertram et al., 2011). The RH in this flow cell was then increased to over $100 \%$, which resulted in growth of the SOM particles by water uptake. The RH was then maintained over $100 \%$ for $30-60 \mathrm{~min}$ to grow and coagulate the SOM particles. After the growth and coagulation process, the RH was decreased to 80-90\% to evaporate the water. The activation, growth, and coagulation processes resulted in particles having diameters of 20 $60 \mu \mathrm{m}$ (see Fig. 1b). This method of producing 20-60 $\mu \mathrm{m}$ particles was introduced by Renbaum-Wolff et al. (2015).

\subsection{Bead-mobility experiments}

The bead-mobility technique has been described in detail by Renbaum-Wolff et al. (2013b). Insoluble melamine beads ( $\sim 1 \mu \mathrm{m}$ in diameter, Sigma-Aldrich, 86296) were incorporated into the supermicron SOM particles deposited on a hydrophobic substrate by nebulizing a suspension of the melamine beads in water over the supermicron SOM particles. The hydrophobic substrate with the SOM particles was then placed in a flow cell coupled to a light-transmitting microscope (Zeiss Axio Observer, magnification $40 \times$ ). Once the supermicron particles were located in the flow cell, a continuous flow of $\mathrm{N}_{2} / \mathrm{H}_{2} \mathrm{O}$ gas $(\sim 1200 \mathrm{sccm})$ was passed over the supermicron particles. By adjusting the ratio of $\mathrm{N}_{2}$ and $\mathrm{H}_{2} \mathrm{O}$ in the flow, the $\mathrm{RH}$ in the cell was controlled. The RH in the flow cell was measured using a hygrometer with a chilled mirror sensor (General Eastern, Canada), which was calibrated by observing the deliquescence RH for pure ammonium sulfate particles (80.0\% RH at $293 \mathrm{~K}$; Martin, 2000). The uncertainty of the RH was $\pm 0.5 \%$.

The continuous flow of $\mathrm{N}_{2} / \mathrm{H}_{2} \mathrm{O}$ gas caused a shear stress on the surfaces of the SOM particles and resulted in internal circulations within the SOM particles. These internal circulations were quantified by monitoring the movement of the beads within the SOM particles with the optical microscope.
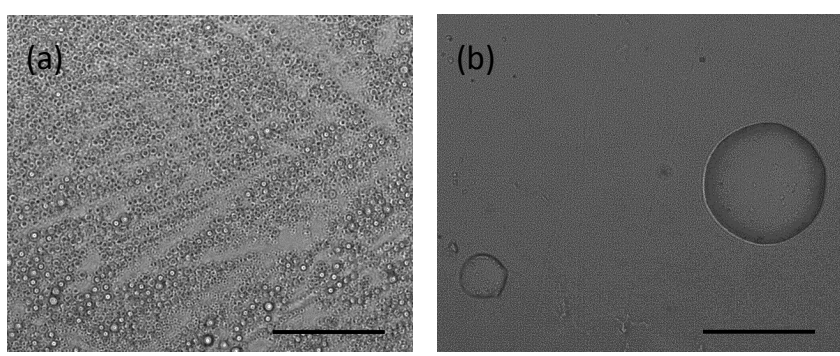

Figure 1. Images of isoprene-derived SOM particles on a hydrophobic substrate. (a) SOM particles after collection from the OFR and (b) SOM particles after being exposed to a cycle droplet growth, coagulation, and evaporation (see text for further details). The samples shown here were produced in the OFR with a concentration of $500-1000 \mu \mathrm{g} \mathrm{m}^{-3}$ (isoprene sample 3 in Table 1). Particles in (a) and (b) were exposed to 0 and $84 \% \mathrm{RH}$, respectively, when the images were recorded. The size of the scale bar is $50 \mu \mathrm{m}$.

Images of the beads within the SOM particles were recorded with a CCD camera every $0.2 \mathrm{~s}-10 \mathrm{~min}$ depending on the velocity of the beads. Typically one to seven beads within a particle were observed over 50-100 frames. Within the same particle, bead speeds varied by a factor of 2-3 depending on the location within the particle. Shown in Fig. 2 are examples of optical images of an isoprene-derived SOM particle at $80 \% \mathrm{RH}$ recorded during a typical bead-mobility experiment. Three beads that were monitored during this experiment are marked with arrows. Also included are the $x$ and $y$ coordinates of the beads recorded at the three different times. From these coordinates the average speed of individual beads in a single particle was determined.

Once the average bead speeds were determined, the bead speeds were converted to viscosity using a calibration line, which was generated from measurements of bead speed as a function of viscosity in sucrose particles (see Fig. 3). Renbaum-Wolff et al. (2013b) showed that the calibration line for converting bead speed into viscosity is independent of the type of organic materials used to generate the line for a wide range of oxygen-to-carbon ratios, surface tensions, and molecular weights of the organic materials.

\subsection{Poke-flow experiment in conjunction with fluid simulation}

The method of applying physical force to estimate the phase of a particle was introduced by Murray et al. (2012). The poke-flow method in conjunction with fluid simulations to determine viscosities of particles was introduced by Renbaum-Wolff et al. (2013a) and further extended and validated by Grayson et al. (2015). Supermicron SOM particles (20-60 $\mu \mathrm{m}$ in diameter) suspended on a hydrophobic substrate were located inside a flow cell with RH control. The flow cell was similar to the one used for the bead-mobility technique except it contained a small hole on the top through which a sterilized sharp needle $(0.9 \mathrm{~mm} \times 40 \mathrm{~mm})$ (Becton- 


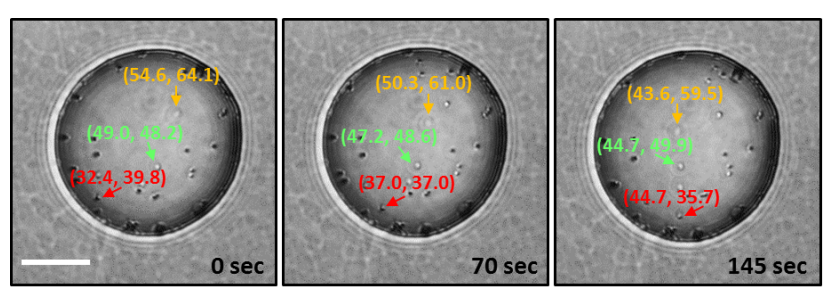

Figure 2. Optical images of SOM particles (isoprene sample 3 in Table 1) at $80 \%$ RH recorded during a typical bead-mobility experiment. Three beads have been labeled in these panels with different colors. Included are the $x$ and $y$ coordinates of these three beads which are used to determine average bead speeds in the particles. The size of the scale bar is $20 \mu \mathrm{m}$.

Dickson, USA) could be inserted. The needle was mounted to a micromanipulator (Narishige, model MO-202U, Japan) to allow precise control of the movement of the needle. The needle was first positioned over the top of a SOM particle and then moved down to pass through the center of the particle (i.e., the particle was poked). The geometrical changes during and after poking a particle were recorded using a reflectance optical microscope (Zeiss Axio Observer, $40 \times$ objective) equipped with a CCD camera.

Figure 4 shows typical geometrical changes of the SOM particles that were observed optically. Prior to poking, the particles had a spherical cap (Fig. 4a1 and b1). Just after poking, the particle had a half-torus geometry consisting of a ring of material with a hole at its center, which is energetically unfavorable (time $t=0$, Fig. $4 \mathrm{a} 2$ and $\mathrm{b} 2$ ). To minimize the surface energy, the material flowed to fill the central hole (Fig. $4 \mathrm{a} 3$ and b3). The area of the inner hole of the halftorus geometry was measured using Zen software (Zeiss, Canada). The diameter of the equivalent hole area was calculated based on the relationship $d=\left(\frac{4 A}{\pi}\right)^{\frac{1}{2}}$, where $d$ is the equivalent area diameter of a hole of area, $A$ (Reist, 1992). The experimental flow time, $\tau_{\text {(exp, flow) }}$, was determined as the time taken for the equivalent area diameter to reach $50 \%$ of the initial value. For a3 and b3 in Fig. 4 , the $\tau_{\text {(exp, flow) }}$ was determined to be $1.3 \mathrm{~s}$ at $26.5 \% \mathrm{RH}$ and $273.9 \mathrm{~s}$ at $0 \%$ $\mathrm{RH}$. The $\tau_{\text {(exp, flow) }}$ values were converted to viscosity using simulations of fluid flow.

Fluid flow simulations were performed to obtain the relationship between viscosity and modeled flow time, $\tau_{\text {(mod, flow) }}$, which is the time when the inner hole of a poked particle reaches half of its initial diameter. Using the relationship between modeled flow time, $\tau_{\text {(mod, flow) }}$, and viscosity, we converted experimental flow time, $\tau_{\text {(exp, flow) }}$, to viscosity. Simulations of material flow were carried out using COMSOL Multiphysics (version 4.3a), which describes transport of mass and momentum, including the effects of surface tension. The arbitrary Lagrangian-Eulerian method was used to track the time evolution of the fluid as it flowed to minimize the surface energy of the system. In the simulation, a half-

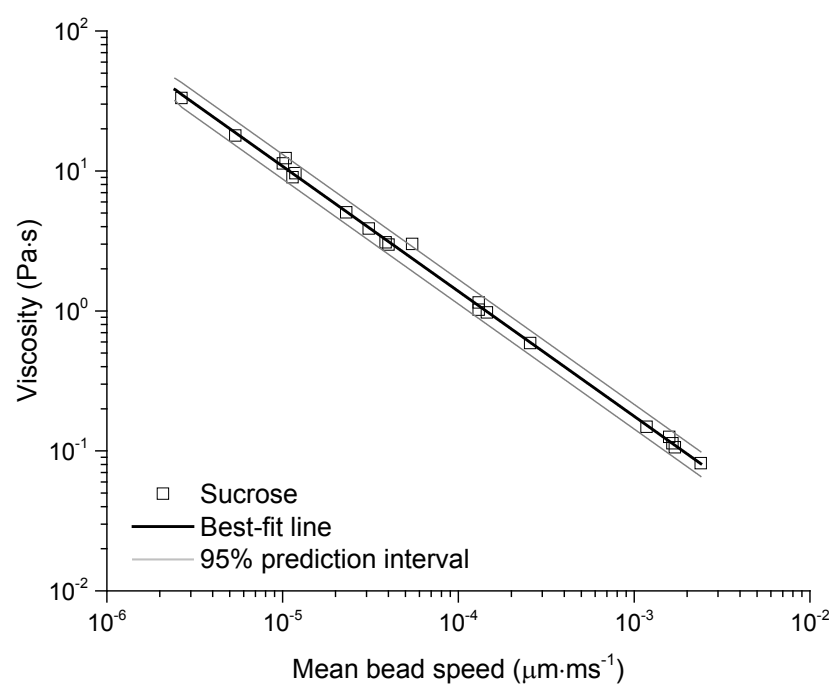

Figure 3. Calibration line (black line) and $95 \%$ prediction intervals (grey lines) that relate mean bead speeds to viscosity. The calibration line was generated using particles consisting of sucrose (squares). Each symbol corresponds to the mean bead speed in one particle determined at the given RH. The speed of one to three beads was used to determine the mean in each particle.

torus geometry consisting of an air-fluid interface and fluidsubstrate interface was used, which is similar to the geometry observed in the poke-flow experiments. The mesh size used in the model was $4.04-90.9 \mathrm{~nm}$. Details of the simulation were described by Grayson et al. (2015).

For the simulations, the following physical parameters were needed: slip length, surface tension, contact angle, and material density for isoprene-derived SOM. Table 2 shows the values used for these physical parameters in the simulations. The lower and upper limits of the slip length used in the simulations were $5 \mathrm{~nm}$ and $10 \mu \mathrm{m}$ based on literature data of the interactions between fluids and solid surfaces (Schnell, 1956; Churaev et al., 1984; Watanabe et al., 1999; Baudry et al., 2001; Craig et al., 2001; Cheng and Giordano, 2002; Tretheway and Meinhart, 2002; Jin et al., 2004; Joseph and Tabeling, 2005; Neto et al., 2005; Choi and Kim et al., 2006; Joly et al., 2006; Zhu et al., 2012; Li et al., 2014). The upper limit for surface tension of SOM was $72 \mathrm{mN} \mathrm{m}^{-1}$, corresponding to the surface tension of pure water at $293 \mathrm{~K}$ (Engelhart et al., 2008), and the lower limit was $17 \mathrm{mN} \mathrm{m}^{-1}$, corresponding to the surface tension of liquid isoprene at $293 \mathrm{~K}$ (http://cameochemicals.noaa.gov). The density of isoprenederived SOM used was based on the observed density of isoprene-derived SOM (Kuwata et al., 2011; Nakao et al., 2013). Contact angles were determined using 3-D fluorescence confocal images of the SOM particles on the substrates, which range from 60 to $90^{\circ}$ (Fig. 5). In the simulation, the relationship between viscosity and contact angle was dependent on the ratio of tube radius to the inner hole radius (see Table 2). Other input to the simulations included 


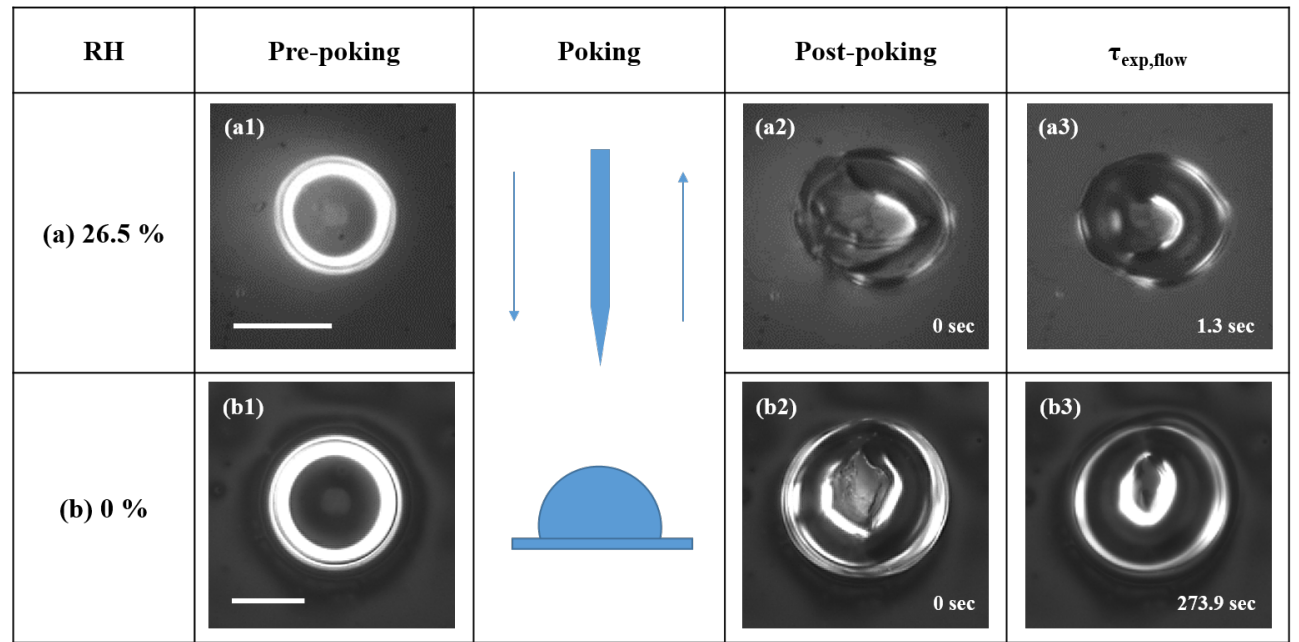

Figure 4. Optical images from typical poke-flow experiments on isoprene-derived SOM at (a) $26.5 \%$ RH and (b) $0 \%$ RH. Panels (a1) and (b1) show pre-poking; panels (a2) and (b2) show post-poking immediately after the needle has been removed (time set $=0 \mathrm{~s}$ ); panels (a3) and (b3) show the experimental flow time, $\tau_{(\exp , \text { flow) }}$, when the diameter of the hole has decreased to $50 \%$ of its initial size. Size of the scale bar is $20 \mu \mathrm{m}$.

Table 2. Physical parameters used to simulate material flow in the poke-flow experiments. $R$ and $r$ indicate the radius of a tube and the radius of an inner hole, respectively.

\begin{tabular}{lrrrr}
\hline & $\begin{array}{r}\text { Slip length } \\
(\mathrm{nm})\end{array}$ & $\begin{array}{r}\text { Surface tension } \\
\left(\mathrm{mN} \mathrm{m}^{-1}\right)\end{array}$ & $\begin{array}{r}\text { Density } \\
\left(\mathrm{g} \mathrm{cm}^{-3}\right)\end{array}$ & $\begin{array}{r}\text { Contact angle } \\
\left({ }^{\circ}\right)\end{array}$ \\
\hline $\begin{array}{l}\text { Values used to } \\
\text { calculate lower limit }\end{array}$ & $5^{\mathrm{a}}$ & $17^{\mathrm{b}}$ & $1.3^{\mathrm{c}}$ & $\begin{array}{r}60 \text { (if } r<2 R), \\
90(\text { if } r>2 R)\end{array}$ \\
$\begin{array}{l}\text { Values used to } \\
\text { calculate upper limit }\end{array}$ & $10000^{\mathrm{a}}$ & $7^{\mathrm{d}}$ & $1.3^{\mathrm{c}}$ & $\begin{array}{r}90(\text { if } r<2 R), \\
60(\text { if } r>2 R)\end{array}$ \\
\hline
\end{tabular}

a The range of slip length, which are the interactions between fluids and solid surfaces, is based on literature data (Schnell, 1956; Churaev et al., 1984; Watanabe et al., 1999; Baudry et al., 2001; Craig et al., 2001; Tretheway and Meinhart, 2002; Cheng and Giordano, 2002; Jin et al., 2004; Joseph and Tabeling, 2005; Neto et al., 2005; Choi and Kim et al., 2006; Joly et al., 2006; Zhu et al., 2012; Li et al., 2014).

${ }^{b}$ http://cameochemicals.noaa.gov. ${ }^{c}$ Kuwata et al. (2011), Nakao et al. (2013). ${ }^{\text {d }}$ Engelhart et al. (2008).

the inner and outer diameters of the torus geometry, which were based on the optical images of the material after poking the particles.

\section{Results}

\subsection{Viscosities of isoprene-derived SOM determined by the bead-mobility technique}

Shown in Fig. 6a are the mean bead speeds as a function of RH at $295 \pm 1 \mathrm{~K}$ determined in the bead-mobility experiments. The different colors represent different samples (Table 1). Each symbol corresponds to the mean bead speed determined for one sample at one RH. The speeds of at least three beads were used to determine a mean bead speed. Figure $6 \mathrm{~b}$ shows viscosities calculated from the mean bead speeds shown in Fig. 6a and the calibration line shown in Fig. 3. The $y$ error bars in Fig. $6 \mathrm{~b}$ represent the $95 \%$ pre- diction intervals from the calibration line. Figure $6 \mathrm{~b}$ illustrates that the change in viscosities with a change in concentration of the SOM in the OFR (when going from 300-400 to $500-1000 \mu \mathrm{g} \mathrm{m}^{-3}$ ) is less than the uncertainties in the measurements. Since the viscosities do not appear to vary with concentrations of the SOM in the OFR over the range studied, we group the data in Fig. $6 \mathrm{~b}$ by RH to provide an overall summary from the bead-mobility technique (see Fig. 6c). Three data points were included in each group. Figure $6 \mathrm{c}$ also illustrates that the viscosity for isoprene-derived SOM increased from $\sim 2 \times 10^{-1}$ to $\sim 3 \times 10^{1} \mathrm{Pas}$ as the RH decreased from 84.5 to $63.7 \%$. Viscosities were not determined for $\mathrm{RH}<60 \%$ using the bead-mobility technique because the circulation rate of beads in a particle became too slow to readily observe. 


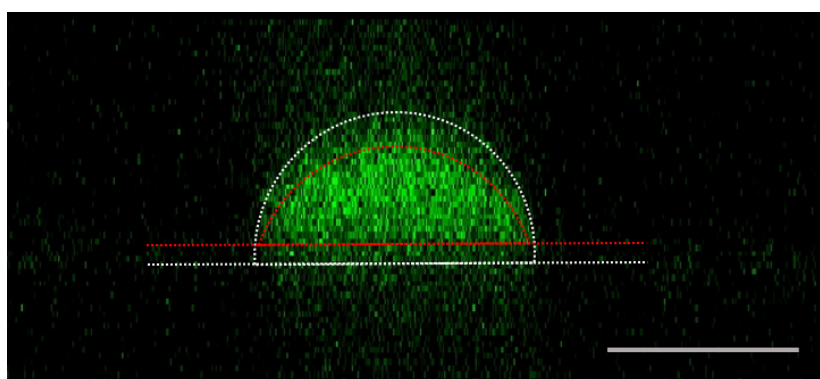

Figure 5. Side-view image of isoprene-derived SOM recorded with a confocal fluorescence microscope (Leica SP5 II, $10 \times$ objective). The image was generated with $\lambda_{\text {excitation }}=458 \mathrm{~nm}$ and $\lambda_{\text {emission }}=465-700 \mathrm{~nm}$ at the temperature of $293 \pm 1 \mathrm{~K}$. The two sets of dashed lines trace the boundaries of the particle from which the contact angle is measured. The white dashed lines encompass the maximum possible boundary with a contact angle of $90^{\circ}$ while the red dashed lines surround the brightest hence the minimum boundary of the particle with a contact angle of $60^{\circ}$. The size of the scale bar is $20 \mu \mathrm{m}$.

\subsection{Viscosities of isoprene-derived SOM determined by the poke-flow technique combined with fluid simulations}

RH-dependent $\tau_{\text {(exp, flow) }}$ values of three different isoprenederived SOM samples measured at $295 \pm 1 \mathrm{~K}$ by the pokeflow technique are shown in Fig. 7a. Each symbol in Fig. 7a represents the measured $\tau_{\text {(exp, flow) }}$ from one particle poked at one RH. Figure 7a illustrates that the variation from sample to sample is less than the variation within individual samples. Figure $7 \mathrm{~b}$ presents the lower and upper limits of viscosities calculated from the individual $\tau_{\text {(exp, flow) }}$ values shown in Fig. 7a. For each data point in Fig. 7b, the uncertainty in the viscosity is approximately 2 orders of magnitude. This uncertainty is due to the uncertainties in the physical parameters used in the simulations (see Table 2). In Fig. 7c, the viscosities of the particles were grouped by RH with at least four data points in each group. The $x$ error bars in Fig. 7b represent the range of RH values in the group as well as uncertainty of the RH measurements. The $y$ error bars represent the lower and upper limits of viscosity within the group. Figure $7 \mathrm{c}$ illustrates that the viscosity ranges from approximately $2 \times 10^{3}$ to $3 \times 10^{5} \mathrm{~Pa}$ s as the RH changes from 25.1 to $0 \% \mathrm{RH}$. Viscosities were not determined for $\mathrm{RH}>30 \%$ using the poke-flow technique because the material flows too fast to observe.

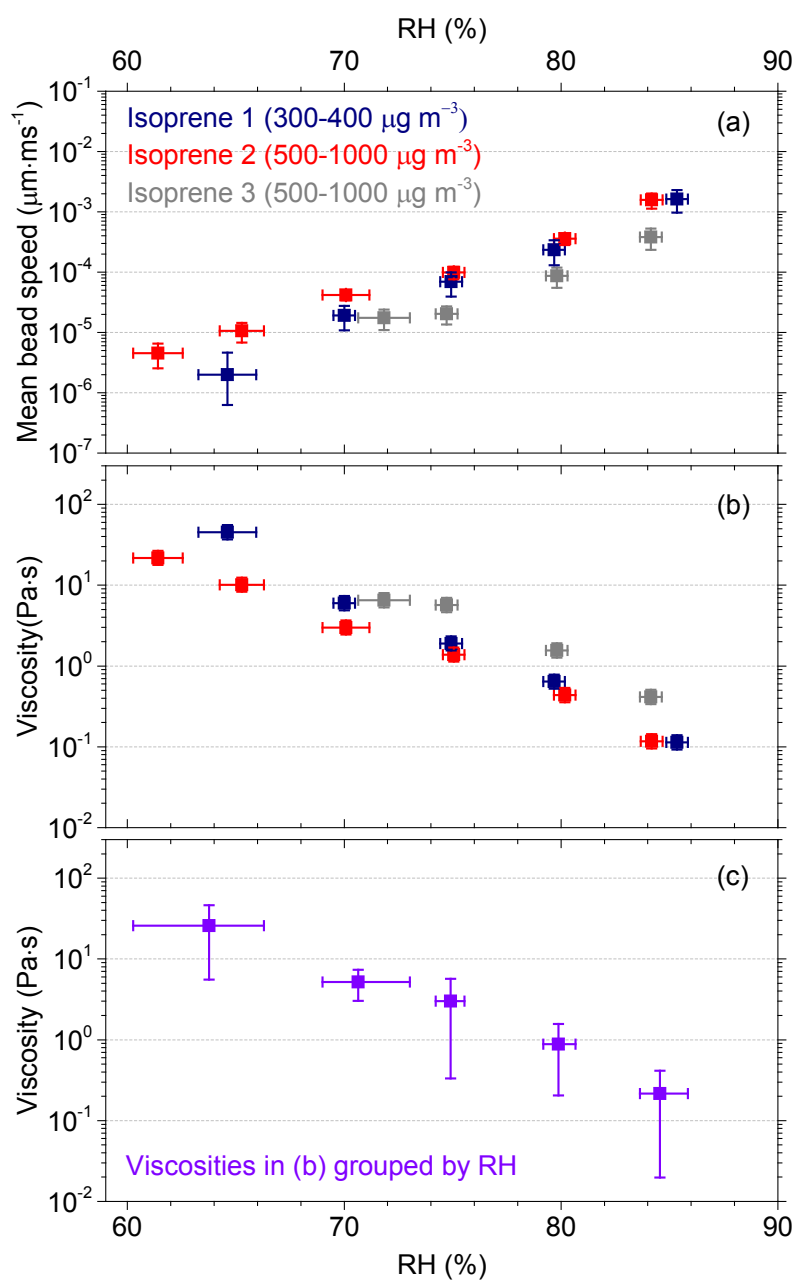

Figure 6. Results from bead-mobility experiments. (a) Mean bead speed of individual SOM samples (i.e., isoprene 1, 2, and 3). Table 1 lists the experimental conditions for each SOM sample. (b) Viscosity was determined from the mean bead speeds and a calibration line (Fig. 3). The $x$ error bars in (a) and (b) represent the RH range in a given experiment and the uncertainty in RH measurements, and the $y$ error bars represent $95 \%$ prediction intervals. (c) Mean viscosities in (b) grouped by RH: three data points were included in each group. The $y$ error bars represent $95 \%$ confidence intervals of viscosities in (b) grouped by $\mathrm{RH}$ and $x$ error bars indicate the lowest and highest $\mathrm{RH}$ ranges in the group and the uncertainty in the $\mathrm{RH}$ measurements.

\section{Discussion}

\subsection{Phase of isoprene-derived SOM as a function of relative humidity}

Figure 8a displays together the viscosities of isoprenederived SOM (marked by purple) measured by the beadmobility technique (Fig. 6c) and the viscosities of isoprenederived SOM measured by the poke-flow technique (Fig. 7c). Based on our data, for $\mathrm{RH}>60 \%$ the isoprene-derived SOM 


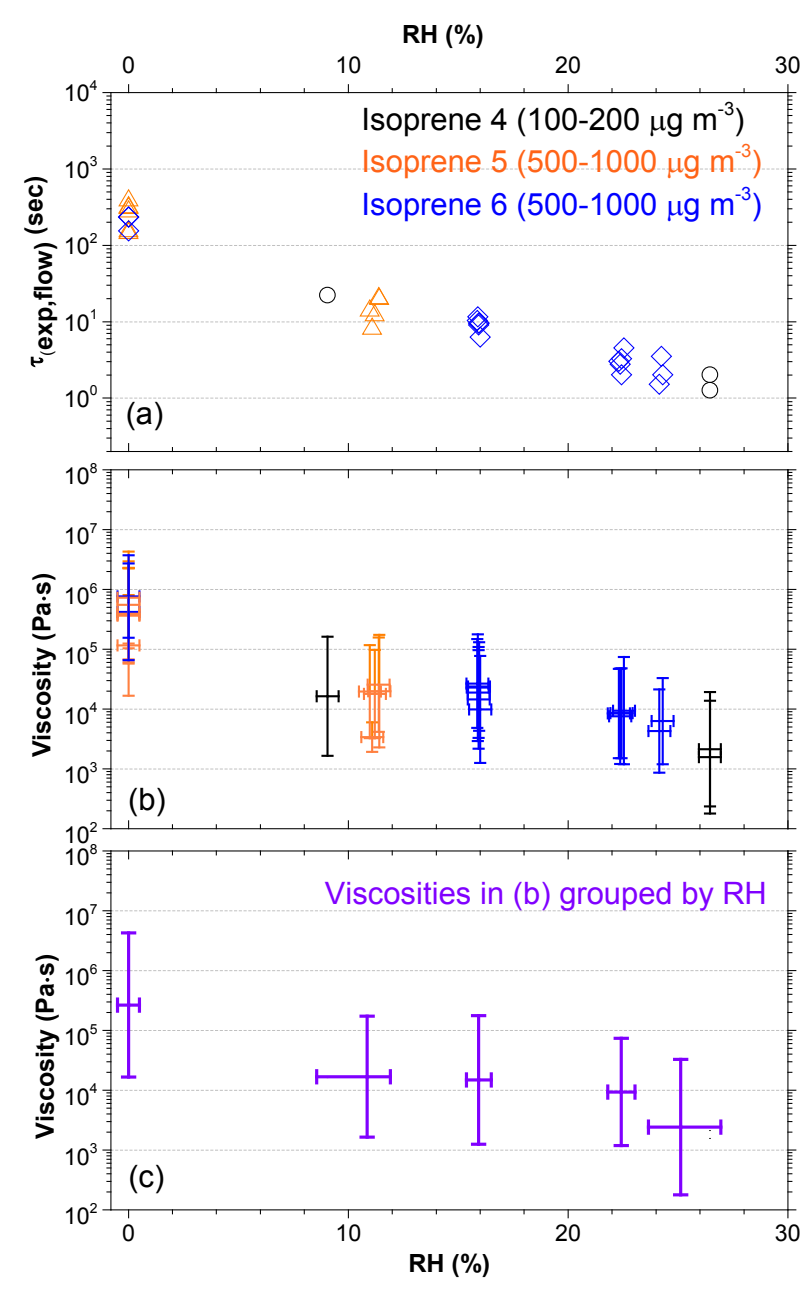

Figure 7. Results from the poke-flow experiments: (a) $\tau_{\text {(exp, flow) }}$ measured for the different samples. Each symbol represents the measured $\tau_{\text {(exp, flow) }}$ from poking one particle at one RH. (b) Viscosities calculated from $\tau_{\text {(exp, flow) }}$ where $y$ error bars represent the calculated lower and upper limits of viscosity using the simulations. The $x$ error bars shown in (b) represent the range of $\mathrm{RH}$ values in a given experiments and uncertainty in the RH measurements. (c) Viscosities from the different samples grouped by RH. At least four data points were included in each group. The $x$ error bars represent the lowest and highest $\mathrm{RH}$ ranges in the group and the uncertainty in the RH measurements, and the $y$ error bars represent the lower and upper limits of viscosity within the group.

falls into the range for a liquid phase (viscosity $<10^{2} \mathrm{~Pa}$ s) while for $\mathrm{RH}<30 \%$ the isoprene-derived SOM falls into the range for a semisolid phase $\left(10^{2} \mathrm{Pas}<\right.$ viscosity $\left.<10^{12} \mathrm{~Pa} \mathrm{~s}\right)$. At no RH is the studied SOM a solid. Based on the rebound behavior of submicron isoprene-derived SOM particles, Bateman et al. (2014) show that the semisolid-to-liquid phase transition of these particles is in the range of 40-60\% $\mathrm{RH}$ for a viscosity transition in the range of $10^{2}$ to $10^{0} \mathrm{Pas}$ (light blue in Fig. 8a). Saukko et al. (2012) measured the bounce fraction of SOM submicron particles derived from isoprene photo-oxidation and inferred from their results that the particles were semisolid or solid for $<55 \% \mathrm{RH}$. Our results are consistent with these previous bounce and rebound experiments.

\subsection{Comparison of viscosities of isoprene-derived SOM and $\alpha$-pinene-derived SOM}

Viscosities of SOM generated from the ozonolysis of $\alpha$ pinene are shown in Fig. $8 \mathrm{~b}$ based on values reported in the literature (Perraud et al., 2012; Abramson et al., 2013; Robinson et al., 2013; Bateman et al., 2014; Kidd et al., 2014; Pajunoja et al., 2014; Wang et al., 2014). The RH-dependent viscosities of the water-soluble component of SOM generated from the ozonolysis of $\alpha$-pinene are also included in Fig. 8b (Renbaum-Wolff et al., 2013a). The values plotted at $\mathrm{RH}$ values $\geq 70 \%$ and $\mathrm{RH}$ values $\leq 30 \%$ were taken directly from Renbaum-Wolff et al. (2013a). Between 40 and $70 \%$ we determined viscosities by converting $\tau_{\text {(exp, flow) }}$ values reported in Renbaum-Wolff et al. (2013a) to viscosities using the simulation discussed above (Sect. 2.4) and presented in Grayson et al. (2015). For RH values between 40 and $70 \%$, we did not take the viscosities directly from Renbaum-Wolff et al. (2013a) since they only used simulations to estimate upper limits to viscosities in this RH range.

Based on a comparison of Fig. 8a and b, the viscosity of isoprene-derived SOM (Fig. 8a) is on average lower than the viscosity of $\alpha$-pinene-derived SOM (Fig. 8b). This conclusion is consistent with work by O'Brien et al. (2014) who also concluded that the viscosity of isoprene-derived particles is lower than the viscosity of $\alpha$-pinene-derived particles based on the how much the particles flattened after impaction on a substrate. The differences may be due to a difference in the molecular weights of the two SOMs since viscosity can increase as the molecular weight of an organic compound increases (Zobrist et al., 2008; Koop et al., 2011). Although we do not have information on the characteristic range of molecular weights of the SOM, it is reasonable to expect that the median molecular weight of $\alpha$-pinene-derived SOM will be larger than that of isoprene-derived SOM since the molecular weight of the precursors differ roughly by a factor of 2. The $\mathrm{O}: \mathrm{C}$ ratio is also expected to affect the viscosity of the SOM, with higher $\mathrm{O}: \mathrm{C}$ values leading to higher viscosities and glass transition temperatures (Koop et al., 2011; Berkemeier et al., 2014). However, O : C alone is unlikely to explain the difference in viscosity between isoprene-derived SOM and $\alpha$-pinene-derived SOM since the $\mathrm{O}: \mathrm{C}$ of isoprenederived SOM in our experiments is expected to be between 0.64 and 1.1 (see Sect. 2.1) while the O : C of SOM from the ozonolysis of $\alpha$-pinene is typically in the range of 0.3 to 0.5 (Chen et al., 2011). 


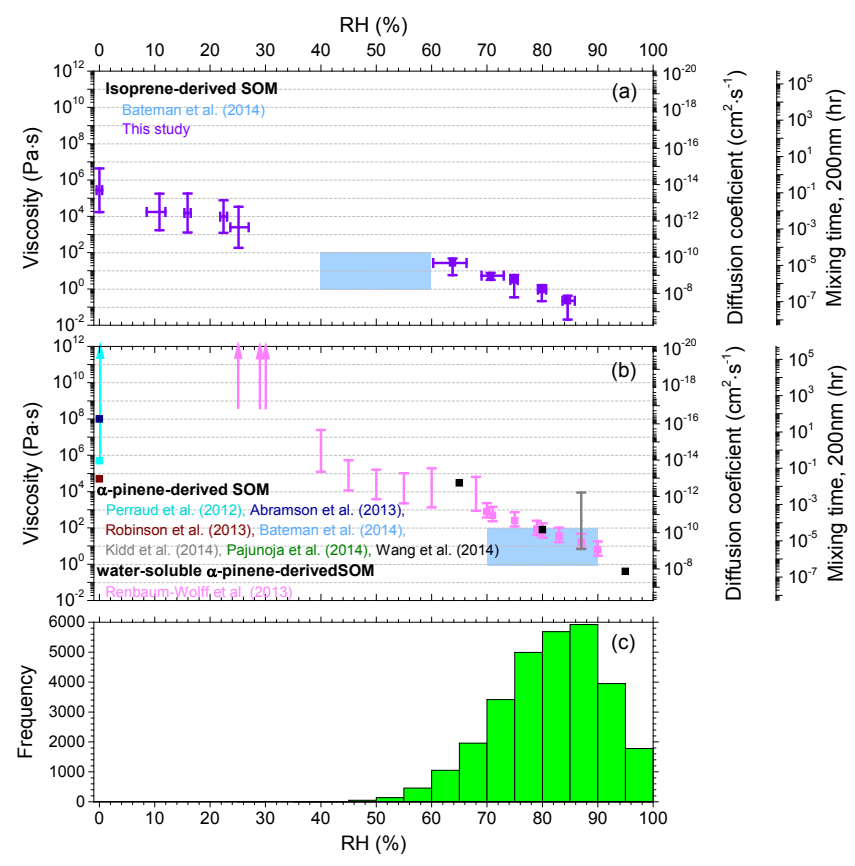

Figure 8. (a) Collection of viscosities of isoprene-derived SOM particles from this study (purple) and Bateman et al. (2014) (light blue). Viscosities of isoprene-derived SOM from this study are taken from values shown in Figs. 6c and 7c. (b) Viscosities of $\alpha$ pinene-derived SOM particles from literature (Perraud et al., 2012, cyan; Abramson et al., 2013, dark blue; Robinson et al., 2013, brown; Bateman et al., 2014, light blue; Kidd et al., 2014, grey; Pajunoja et al., 2014, green; and Wang et al., 2014, black) and viscosities of water-soluble $\alpha$-pinene-derived SOM particles from Renbaum-Wolff et al. (2013a) (pink). The right $y$ axes present calculated diffusion coefficients of organic molecules in SOM and calculated mixing times within $200 \mathrm{~nm}$ particles due to bulk diffusion. Diffusion coefficients were calculated using the StokesEinstein relation and mixing times were calculated using Eq. (2) (see Sect. 4.3). (c) The average frequency distributions of RH from eight stations in the Amazon Basin (Tabatinga, Barcelos, Itaituba, Monte Dourado, Iquitos, Lábrea, Manicoré, and Manaus). Frequency distributions of RH from the individual stations are shown in Fig. 9.

\subsection{Diffusion coefficients and mixing times of large organics within isoprene-derived SOM particles}

Using the viscosities determined in this study, we calculated diffusion coefficients of large organic molecules $\left(D_{\text {org }}\right)$ within isoprene-derived SOM using the Stokes-Einstein relationship:

$D_{\text {org }}=\frac{k T}{6 \pi \eta r}$,

where $k$ is the Boltzmann constant, $T$ is the temperature (K), $r$ is the hydrodynamic radius of a representative molecule of SOM within the SOM bulk matrix, and $\eta$ is the viscosity (Pa s). The Stokes-Einstein relation is not expected to predict with high accuracy the diffusion rates of small gas molecules (e.g., $\mathrm{O}_{3}, \mathrm{OH}, \mathrm{NO}_{x}, \mathrm{H}_{2} \mathrm{O}$ ) close to the glass transition $\mathrm{RH}$ (Champion et al., 2000; Shiraiwa et al., 2011; Power et al., 2013). However, the Stokes-Einstein relation should give a reasonable estimate of diffusion rates when the viscosity is lower than that of a glass and when the molecules undergoing diffusion are roughly the same size or larger than the molecules in the SOM matrix. When we assume the SOM matrix is dominated by molecules similar to 2-methyltetrol and 2-methylerythritol $\left(\mathrm{C}_{5} \mathrm{H}_{12} \mathrm{O}_{4}\right)$, which have been identified as key oxidation productions of isoprene and have an isoprene skeleton (Cleaeys et al., 2004; Carlton et al., 2009; Kleindienst et al., 2009), then the Stokes-Einstein equation should be applicable when the viscosity is lower than that of a glass $\left(10^{12} \mathrm{~Pa} \mathrm{~s}\right)$ and for organic molecules with a molecular weight approximately $\geq 136 \mathrm{~g} \mathrm{~mol}^{-1}$, although additional work is required to confirm these assumptions.

Shown in Fig. 8a on a secondary $y$ axis are the diffusion coefficients calculated using this equation and assuming $0.4 \mathrm{~nm}$ for the hydrodynamic radius (Renbaum-Wolff et al., 2013a). Figure 8a suggests that the diffusion coefficients of organic molecules within the isoprene-derived SOM vary from $\sim 2 \times 10^{-8}$ to $\sim 2 \times 10^{-10} \mathrm{~cm}^{2} \mathrm{~s}^{-1}$ between 84.5 and $63.7 \% \mathrm{RH}$ and from $\sim 2 \times 10^{-12}$ to $\sim 2 \times 10^{-14} \mathrm{~cm}^{2} \mathrm{~s}^{-1}$ between 25.1 and $0 \% \mathrm{RH}$.

From the diffusion coefficients, we calculated the mixing times by diffusion, $\tau_{\text {mixing }}$, of large organic molecules within an SOM particle using the following equation (Shiraiwa et al., 2011; Bones et al., 2012; Renbaum-Wolff et al., 2013a):

$\tau_{\text {mixing }}=\frac{d^{2}}{4 \pi^{2} D_{\mathrm{org}}}$,

where $d$ is the particle diameter (taken as $200 \mathrm{~nm}$, which is typical for the accumulation mode of atmospheric particles; Shiraiwa et al., 2011). After the mixing time, the concentration of the representative molecules anywhere in the particles deviates by less than $e^{-1}$ from the equilibrium value. The mixing times calculated with Eq. (2) are plotted in Fig. 8a on a secondary $y$ axis. Between 84.5 and $0 \%$ $\mathrm{RH}$, the mixing times within the isoprene-derived SOM particles range from less than $\sim 3.6 \times 10^{-4} \mathrm{~s}\left(\sim 1 \times 10^{-7} \mathrm{~h}\right)$ to $\sim 0.1 \mathrm{~h}$. Compared to the total isoprene-derived SOM, watersoluble $\alpha$-pinene-derived SOM shows longer mixing times ranging from $\sim 1.1 \times 10^{-2} \mathrm{~s}\left(\sim 3 \times 10^{-6} \mathrm{~h}\right)$ to as high as $\sim 5 \times 10^{5} \mathrm{~h}$ over the RH range of 90 to $25 \%$. Both isoprenederived and $\alpha$-pinene-derived SOM can be classified as biogenic SOM, yet they clearly have different viscosities and mixing times at a given $\mathrm{RH}$.

\section{Atmospheric implications}

As an application of the data discussed above, we consider a case study for the Amazon Basin, which represents the 
largest isoprene-dominant forested region on Earth. We assess $\tau_{\text {mixing }}$ within SOM particles in the Amazon Basin during periods not strongly influenced by anthropogenic emissions (Martin et al., 2010b). The wet season in the Amazon Basin represents at times a clean environment having nearly pure biogenic aerosol particles. For clean conditions, SOM typically accounts for $>95 \%$ of the mass of aerosol particles with diameters $<1 \mu \mathrm{m}$ in the Amazon Basin (Chen et al., 2009; Martin et al., 2010a). The dry season can also have periods dominated by biogenic aerosol particles, but periods strongly influenced by anthropogenic sources such as biomass burning are also common (Andreae et al., 2002; Martin et al., 2010a, b).

To assess the $\tau_{\text {mixing }}$ of SOM particles in the Amazon Basin during clean periods, the first piece of information needed is the range of $\mathrm{RH}$ values in this region. Figure 9 gives a frequency distribution of RH for eight ground-based observation stations in the Amazon Basin (located in Tabatinga, Barcelos, Itaituba, Monte Dourado, Iquitos, Lábrea, Manicoré, and Manaus) for both the wet season (December to March, shown in blue bars) and the dry season (June to September, shown in red bars). The RH values used in these frequency distributions were taken from NOAA's National Climatic Data Center (NCDC) (http://www.ncdc.noaa.gov/) and are $12 \mathrm{~h}$ averages (daytime: 06:00-18:00, nighttime: 18:00-06:00 LT) calculated from hourly values reported several times daily for the years of 2004 through 2014. All RH values taken from NOAA's NCDC were calculated from measured temperatures and dew points. The eight stations shown in Fig. 9 were chosen because they had good data records and were well spaced geographically throughout the Basin. As shown in Fig. 9, RH typically ranges between 60 and $100 \%$ during both dry and wet seasons in the Amazon Basin although there is some variability with location and season. Figure $8 \mathrm{c}$ shows a frequency distribution of $12 \mathrm{~h}$ average RH in the Amazon Basin using the data from all eight ground-based stations from both the wet and dry seasons. Figures 9 and $8 \mathrm{c}$ illustrate that RH typically ranges from 60 to $100 \%$ in the Amazon Basin. Values below $60 \%$ RH are rare.

The second piece of information needed to assess $\tau_{\text {mixing }}$ for SOM is temperature. For the eight ground-based stations shown in Fig. 9, for both the wet and dry seasons the median temperature was $300 \mathrm{~K}$ and the 10th and 90th percentiles were 297 and $303 \mathrm{~K}$, respectively. These temperatures are above the estimated glass transition of a generic SOM (Koop et al., 2011). The viscosities shown in Fig. 8a were determined using a temperature of $295 \pm 1 \mathrm{~K}$, which is at the lower end of the temperature range for the Amazon. As temperature increases the viscosity is expected to decrease for the same composition of water and SOM.

The third piece of information needed to assess $\tau_{\text {mixing }}$ for SOM in the Amazon Basin during clean conditions is the chemical composition of the SOM during these periods. Previous studies have shown by multiple lines of evi-

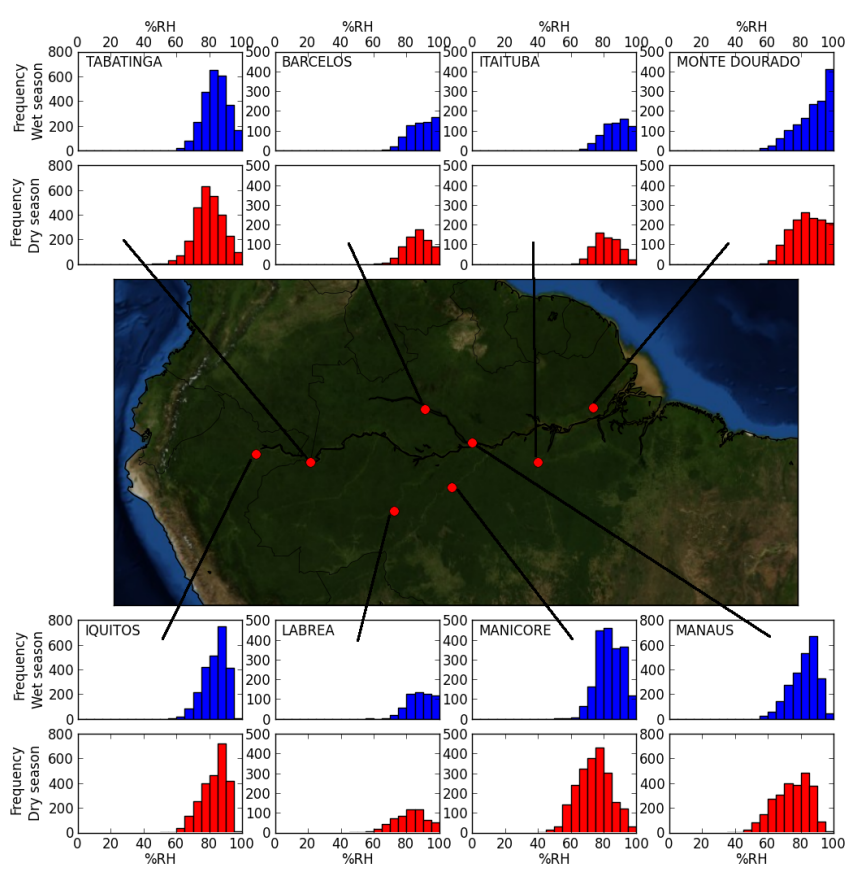

Figure 9. Frequency distributions of RH for the wet season (December-March, shown in blue) and the dry season (JuneSeptember, shown in red) at eight ground-based stations in the Amazon Basin. For the stations, hourly RH values (calculated from measured temperature and dew point) were retrieved from NOAA's National Climatic Data Center (http://www.ncdc.noaa.gov/) for the years from 2004 to 2014 . All data shown are $12 \mathrm{~h}$ averages.

dence that during clean conditions the composition of submicron organic particles is largely consistent with SOM generated from isoprene and terpene oxidation as well as a sesquiterpene contribution (Chen et al., 2009; Martin et al., 2010a; Pöschl et al., 2010; Pöhlker et al., 2012; Chen et al., 2015). Based on these studies, we model SOM particles in the Amazon Basin during clean conditions as a mixture of isoprene-derived SOM, $\alpha$-pinene-derived SOM, and other VOC-precursor-derived SOM. Furthermore, we make a firstorder approximation for modeling that the SOM can be adequately described as a mix of isoprene-derived and $\alpha$-pinenederived SOM since we have the necessary corresponding data on viscosity. We also assume that the $\tau_{\text {mixing }}$ in these particles lies somewhere between the $\tau_{\text {mixing }}$ in isoprene-derived SOM and the $\tau_{\text {mixing }}$ in $\alpha$-pinene-derived SOM shown in Fig. 8a and b. Bateman et al. (2014) studied mixed SOM particles and found that the viscosity of single particles decreased with an increase in the ratio of gas-phase isoprene to $\alpha$-pinene precursors. Based on these assumptions and the typical RH and temperature values found in the Amazon Basin, we estimate the $\tau_{\text {mixing }}$ of SOM particles in the Amazon Basin during clean conditions will be less than or equal to approximately $0.1 \mathrm{~h}$. Large-scale modeling studies often assume that gas-phase organic compounds are rapidly equilibrated within the bulk of SOM particles (Henze and Seinfeld, 
2006; Tsigaridis and Kanakidou, 2007; Heald et al., 2008). Our results and conclusions are consistent with this assumption for the Amazon Basin during clean periods.

Using the data shown in Fig. 8 we also speculate on the phase of SOM in the Amazon Basin during clean periods. For this analysis we also make the first-order approximation that the SOM in this region can be adequately described as a mix of isoprene-derived and $\alpha$-pinene-derived SOM and that the viscosity of these particles lies somewhere between the viscosities of isoprene-derived SOM and $\alpha$-pinene-derived SOM shown in Fig. 8a and b. Based on these assumptions and typical RH values (> 60\%) and temperature ranges (297$303 \mathrm{~K}$ ) found in the Amazon Basin (Fig. 8c), the SOM particles during clean conditions are likely liquid. This conclusion is consistent with the images of Amazonian particles collected by Pöschl et al. (2010) that illustrate the particles are liquid during the wet season (AMAZE-08). This conclusion is also consistent with results from Chen et al. (2015), who inferred that SOM particles in the Amazon Basin are liquid based on the absence of particle rebound when sampling with an aerosol mass spectrometer.

One caveat to the conclusions above is that the mass concentrations used in our studies differ from the mass concentrations observed in the Amazon Basin. The mass concentrations of SOM observed in the Amazon Basin during the wet season are on order of $1 \mu \mathrm{g} \mathrm{m}^{-3}$ for the submicron mode (Martin et al., 2010a), while we used mass concentrations of 100 to $1000 \mu \mathrm{g} \mathrm{m}^{-3}$ when generating isoprene-derived SOM due to experimental constraints. We did not see any dependence on mass concentration across the studied range. Furthermore, the study of Bateman et al. (2014) was carried out at lower mass concentrations of $10-20 \mu \mathrm{g} \mathrm{m}^{-3}$, and those results appear to agree with our results in Fig. 8a. Even so, additional studies are needed to determine whether lower mass concentrations of isoprene-derived SOM approaching $1 \mu \mathrm{g} \mathrm{m}^{-3}$ might lead to higher viscosities.

\section{Conclusions}

We investigated RH-dependent viscosities of micrometersized SOM particles produced from isoprene photooxidation and having mass concentrations of 100 to $1000 \mu \mathrm{g} \mathrm{m}^{-3}$ using a bead-mobility technique and a pokeflow technique combined with fluid simulations. At room temperature, the bead-mobility experiments showed the viscosities of isoprene-derived SOM increased from $\sim 2 \times 10^{-1}$ to $\sim 3 \times 10^{1} \mathrm{Pas}$ when the RH was decreased from 84.5 to $63.7 \%$. The poke-flow experiments and fluid simulation showed viscosities of isoprene-derived SOM increased from $\sim 2 \times 10^{3}$ to $\sim 3 \times 10^{5} \mathrm{Pas}$ when the RH decreased from 25.1 to $0 \%$. This suggests that the isoprene-derived SOM particles are a liquid at $\mathrm{RH}>\sim 60 \%$ and a semisolid at $\mathrm{RH}<\sim 30 \%$. This result is in agreement with Bateman et al. (2014), who showed that the semisolid-to-liquid phase transition of these particles is in the range of $40-60 \% \mathrm{RH}$, as well as with Saukko et al. (2012) who inferred that these particles are a semisolid or solid at RH $<55 \%$. Using the viscosity data and the Stokes-Einstein equation, the diffusion coefficients of large gas-phase organic molecules within the isoprene-derived SOM particles were calculated to be $\sim 2 \times 10^{-8}$ to $\sim 2 \times 10^{-14} \mathrm{~cm}^{2} \mathrm{~s}^{-1}$ between 84.5 and $0 \%$ $\mathrm{RH}$. Mixing time ( $\tau_{\text {mixing }}$ ) by diffusion of large organic molecules within $200 \mathrm{~nm}$ isoprene-derived SOM particles was also estimated to range from less than $1 \mathrm{~s}$ to $\sim 0.1 \mathrm{~h}$ across the $\mathrm{RH}$ range.

The Amazon Basin is an environment rich in biogenic SOM derived from isoprene and $\alpha$-pinene. Based on the distributions of $\mathrm{RH}$ and temperature seen at eight stations in the Amazon Basin, $\mathrm{RH}$ and temperature typically range from 60 to $100 \%$ and 297 to $303 \mathrm{~K}$ during wet and dry seasons in this region, respectively. Based on these RH and temperature values and assumptions about the dominant chemical compositions of SOM particles, we concur with the laboratory study of Bateman et al. (2014) and expect SOM particles to be liquid in the Amazon Basin during pristine conditions. In addition, we expect large gas-phase organic molecules to reach equilibrium with the bulk of these SOM particles on a short time scale.

Acknowledgements. We thank Katie Potter, James W. Grayson, and Saeid Kamal for experimental and technical support and Adam P. Bateman for helpful input on the manuscript. This work was supported by the Natural Sciences and Engineering Research Council of Canada. Support from the US National Science Foundation and the US Department of Energy is also acknowledged.

Edited by: T. Bertram

\section{References}

Abramson, E., Imre, D., Beranek, J., Wilson, J., and Zelenyuk, A.: Experimental determination of chemical diffusion within secondary organic aerosol particles, Phys. Chem. Chem. Phys., 15, 2983-2991, doi:10.1039/C2cp44013j, 2013.

Andreae, M. O., Artaxo, P., Brandao, C., Carswell, F. E., Ciccioli, P., da Costa, A. L., Culf, A. D., Esteves, J. L., Gash, J. H. C., Grace, J., Kabat, P., Lelieveld, J., Malhi, Y., Manzi, A. O., Meixner, F. X., Nobre, A. D., Nobre, C., Ruivo, M. D. L. P., Silva-Dias, M. A., Stefani, P., Valentini, R., von Jouanne, J., and Waterloo, M. J.: Biogeochemical cycling of carbon, water, energy, trace gases, and aerosols in Amazonia: The LBA-EUSTACH experiments, J. Geophys. Res.-Atmos., 107, 8066, doi:10.1029/2001jd000524, 2002.

Baltensperger, U., Dommen, J., Alfarra, R., Duplissy, J., Gaeggeler, K., Metzger, A., Facchini, M. C., Decesari, S., Finessi, E., Reinnig, C., Schott, M., Warnke, J., Hoffmann, T., Klatzer, B., Puxbaum, H., Geiser, M., Savi, M., Lang, D., Kalberer, M., and Geiser, T.: Combined determination of the chemical composition and of health effects of secondary organic aerosols: The 
POLYSOA project, J. Aerosol. Med. Pulm. D., 21, 145-154, doi:10.1089/jamp.2007.0655, 2008.

Bateman, A. P., Bertram, A. K., and Martin, S. T.: Hygroscopic Influence on the Semisolid-to-Liquid Transition of Secondary Organic Materials, J. Phys. Chem. A., doi:10.1021/jp508521c, 2014.

Baudry, J., Charlaix, E., Tonck, A., and Mazuyer, D.: Experimental evidence for a large slip effect at a nonwetting fluid-solid interface, Langmuir, 17, 5232-5236, doi:10.1021/La0009994, 2001.

Berkemeier, T., Shiraiwa, M., Pöschl, U., and Koop, T.: Competition between water uptake and ice nucleation by glassy organic aerosol particles, Atmos. Chem. Phys., 14, 12513-12531, doi:10.5194/acp-14-12513-2014, 2014.

Bertram, A. K., Martin, S. T., Hanna, S. J., Smith, M. L., Bodsworth, A., Chen, Q., Kuwata, M., Liu, A., You, Y., and Zorn, S. R.: Predicting the relative humidities of liquid-liquid phase separation, efflorescence, and deliquescence of mixed particles of ammonium sulfate, organic material, and water using the organic-to-sulfate mass ratio of the particle and the oxygen-tocarbon elemental ratio of the organic component, Atmos. Chem. Phys., 11, 10995-11006, doi:10.5194/acp-11-10995-2011, 2011.

Bodsworth, A., Zobrist, B., and Bertram, A. K.: Inhibition of efflorescence in mixed organic-inorganic particles at temperatures less than 250 K, Phys. Chem. Chem. Phys., 12, 15144-15144, 2010.

Bones, D. L., Reid, J. P., Lienhard, D. M., and Krieger, U. K.: Comparing the mechanism of water condensation and evaporation in glassy aerosol, P. Natl. Acad. Sci. USA, 109, 11613-11618, doi:10.1073/pnas.1200691109, 2012.

Budisulistiorini, S. H., Canagaratna, M. R., Croteau, P. L., Marth, W. J., Baumann, K., Edgerton, E. S., Shaw, S. L., Knipping, E. M., Worsnop, D. R., Jayne, J. T., Gold, A., and Surratt, J. D.: Real-Time Continuous Characterization of Secondary Organic Aerosol Derived from Isoprene Epoxydiols in Downtown Atlanta, Georgia, Using the Aerodyne Aerosol Chemical Speciation Monitor, Environ. Sci. Technol., 47, 5686-5694, doi:10.1021/Es400023n, 2013.

Canagaratna, M. R., Jimenez, J. L., Kroll, J. H., Chen, Q., Kessler, S. H., Massoli, P., Hildebrandt Ruiz, L., Fortner, E., Williams, L. R., Wilson, K. R., Surratt, J. D., Donahue, N. M., Jayne, J. T., and Worsnop, D. R.: Elemental ratio measurements of organic compounds using aerosol mass spectrometry: characterization, improved calibration, and implications, Atmos. Chem. Phys., 15, 253-272, doi:10.5194/acp-15-253-2015, 2015.

Cappa, C. D. and Wilson, K. R.: Evolution of organic aerosol mass spectra upon heating: implications for OA phase and partitioning behavior, Atmos. Chem. Phys., 11, 1895-1911, doi:10.5194/acp11-1895-2011, 2011.

Carlton, A. G., Wiedinmyer, C., and Kroll, J. H.: A review of Secondary Organic Aerosol (SOA) formation from isoprene, Atmos. Chem. Phys., 9, 4987-5005, doi:10.5194/acp-9-4987-2009, 2009.

Champion, D., Le Meste, M., and Simatos, D.: Towards an improved understanding of glass transition and relaxations in foods: molecular mobility in the glass transition range, Trends. Food. Sci. Tech., 11, 41-55, doi:10.1016/S0924-2244(00)000479, 2000.

Chen, Q., Farmer, D. K., Schneider, J., Zorn, S. R., Heald, C. L., Karl, T. G., Guenther, A., Allan, J. D., Robinson, N., Coe, H.,
Kimmel, J. R., Pauliquevis, T., Borrmann, S., Pöschl, U., Andreae, M. O., Artaxo, P., Jimenez, J. L., and Martin, S. T.: Mass spectral characterization of submicron biogenic organic particles in the Amazon Basin, Geophys. Res. Lett., 36, L20806, doi:10.1029/2009g1039880, 2009.

Chen, Q., Liu, Y. J., Donahue, N. M., Shilling, J. E., and Martin, S. T.: Particle-Phase Chemistry of Secondary Organic Material: Modeled Compared to Measured O : C and H: C Elemental Ratios Provide Constraints, Environ. Sci. Technol., 45, 4763-4770, doi:10.1021/Es104398s, 2011.

Chen, Q., Farmer, D. K., Rizzo, L. V., Pauliquevis, T., Kuwata, M., Karl, T. G., Guenther, A., Allan, J. D., Coe, H., Andreae, M. O., Pöschl, U., Jimenez, J. L., Artaxo, P., and Martin, S. T.: Submicron particle mass concentrations and sources in the Amazonian wet season (AMAZE-08), Atmos. Chem. Phys., 15, 3687-3701, doi:10.5194/acp-15-3687-2015, 2015.

Cheng, J. T. and Giordano, N.: Fluid flow through nanometer-scale channels, Phys. Rev. E, 65, 031206, doi:10.1103/Physreve.65.031206, 2002.

Chhabra, P. S., Flagan, R. C., and Seinfeld, J. H.: Elemental analysis of chamber organic aerosol using an aerodyne high-resolution aerosol mass spectrometer, Atmos. Chem. Phys., 10, 4111-4131, doi:10.5194/acp-10-4111-2010, 2010.

Choi, C. H. and Kim, C. J.: Large slip of aqueous liquid flow over a nanoengineered superhydrophobic surface, Phys. Rev. Lett., 96, 066001, doi:10.1103/Physrevlett.96.066001, 2006.

Churaev, N. V., Sobolev, V. D., and Somov, A. N.: Slippage of Liquids over Lyophobic Solid-Surfaces, J. Colloid Interf. Sci., 97, 574-581, doi:10.1016/0021-9797(84)90330-8, 1984.

Claeys, M., Graham, B., Vas, G., Wang, W., Vermeylen, R., Pashynska, V., Cafmeyer, J., Guyon, P., Andreae, M. O., Artaxo, P., and Maenhaut, W.: Formation of secondary organic aerosols through photooxidation of isoprene, Science, 303, 1173-1176, doi:10.1126/science.1092805, 2004.

Craig, V. S. J., Neto, C., and Williams, D. R. M.: Shear-dependent boundary slip in an aqueous Newtonian liquid, Phys. Rev. Lett., 87, 054504, doi:10.1103/Physrevlett.87.054504, 2001.

Engelhart, G. J., Asa-Awuku, A., Nenes, A., and Pandis, S. N.: CCN activity and droplet growth kinetics of fresh and aged monoterpene secondary organic aerosol, Atmos. Chem. Phys., 8, 39373949, doi:10.5194/acp-8-3937-2008, 2008.

Fu, P. Q., Kawamura, K., Kanaya, Y., and Wang, Z. F.: Contributions of biogenic volatile organic compounds to the formation of secondary organic aerosols over Mt Tai, Central East China, Atmos. Environ., 44, 4817-4826, doi:10.1016/j.atmosenv.2010.08.040, 2010.

Geron, C., Guenther, A., Sharkey, T., and Arnts, R. R.: Temporal variability in basal isoprene emission factor, Tree Physiol., 20, 799-805, 2000.

Grayson, J. W., Song, M., Sellier, M., and Bertram, A. K.: Validation of the poke-flow technique combined with simulations of fluid flow for determining viscosities in samples with small volumes and high viscosities, Atmos. Meas. Tech. Discuss., 8, 877903, doi:10.5194/amtd-8-877-2015, 2015.

Guenther, A., Hewitt, C. N., Erickson, D., Fall, R., Geron, C., Graedel, T., Harley, P., Klinger, L., Lerdau, M., Mckay, W. A., Pierce, T., Scholes, B., Steinbrecher, R., Tallamraju, R., Taylor, J., and Zimmerman, P.: A Global-Model of Natural Volatile 
Organic-Compound Emissions, J. Geophys. Res.-Atmos., 100, 8873-8892, doi:10.1029/94jd02950, 1995.

Hakola, H., Laurila, T., Rinne, J., and Puhto, K.: The ambient concentrations of biogenic hydrocarbons at a northern European, boreal site, Atmos. Environ., 34, 4971-4982, doi:10.1016/S13522310(00)00192-8, 2000.

Hallquist, M., Wenger, J. C., Baltensperger, U., Rudich, Y., Simpson, D., Claeys, M., Dommen, J., Donahue, N. M., George, C., Goldstein, A. H., Hamilton, J. F., Herrmann, H., Hoffmann, T., Iinuma, Y., Jang, M., Jenkin, M. E., Jimenez, J. L., Kiendler-Scharr, A., Maenhaut, W., McFiggans, G., Mentel, Th. F., Monod, A., Prévôt, A. S. H., Seinfeld, J. H., Surratt, J. D., Szmigielski, R., and Wildt, J.: The formation, properties and impact of secondary organic aerosol: current and emerging issues, Atmos. Chem. Phys., 9, 5155-5236, doi:10.5194/acp-9-51552009, 2009.

Heald, C. L., Henze, D. K., Horowitz, L. W., Feddema, J., Lamarque, J. F., Guenther, A., Hess, P. G., Vitt, F., Seinfeld, J. H., Goldstein, A. H., and Fung, I.: Predicted change in global secondary organic aerosol concentrations in response to future climate, emissions, and land use change, J. Geophys. Res.-Atmos., 113, D05211, doi:10.1029/2007jd009092, 2008.

Henze, D. K. and Seinfeld, J. H.: Global secondary organic aerosol from isoprene oxidation, Geophys. Res. Lett., 33, L09812, doi:10.1029/2006g1025976, 2006.

Henze, D. K., Seinfeld, J. H., Ng, N. L., Kroll, J. H., Fu, T.-M., Jacob, D. J., and Heald, C. L.: Global modeling of secondary organic aerosol formation from aromatic hydrocarbons: highvs. low-yield pathways, Atmos. Chem. Phys., 8, 2405-2420, doi:10.5194/acp-8-2405-2008, 2008.

IPCC: Climate Change 2013: The Physical Science Basis. Contribution of Working Group I to the Fifth Assessment Report of the Intergovernmental Panel on Climate Change, edited by: Stocker, T. F., Qin, D., Plattner, G.-K., Tignor, M., Allen, S. K., Boschung, J., Nauels, A., Xia, Y., Bex, V., and Midgley, P. M., Cambridge University Press, Cambridge, UK and New York, NY, USA, 1535, 2013.

Jang, Y., Kim, G., and Chiriboga, D. A.: Correlates of sense of control among older Korean-American immigrants: Financial status, physical health constraints, and environmental challenges, Int. J. Aging Hum. Dev., 63, 173-186, doi:10.2190/9qmq-Tg4a-1ldcCnrr, 2006.

Jimenez, J. L., Canagaratna, M. R., Donahue, N. M., Prevot, A. S. H., Zhang, Q., Kroll, J. H., DeCarlo, P. F., Allan, J. D., Coe, H., Ng, N. L., Aiken, A. C., Docherty, K. S., Ulbrich, I. M., Grieshop, A. P., Robinson, A. L., Duplissy, J., Smith, J. D., Wilson, K. R., Lanz, V. A., Hueglin, C., Sun, Y. L., Tian, J., Laaksonen, A., Raatikainen, T., Rautiainen, J., Vaattovaara, P., Ehn, M., Kulmala, M., Tomlinson, J. M., Collins, D. R., Cubison, M. J., Dunlea, E. J., Huffman, J. A., Onasch, T. B., Alfarra, M. R., Williams, P. I., Bower, K., Kondo, Y., Schneider, J., Drewnick, F., Borrmann, S., Weimer, S., Demerjian, K., Salcedo, D., Cottrell, L., Griffin, R., Takami, A., Miyoshi, T., Hatakeyama, S., Shimono, A., Sun, J. Y., Zhang, Y. M., Dzepina, K., Kimmel, J. R., Sueper, D., Jayne, J. T., Herndon, S. C., Trimborn, A. M., Williams, L. R., Wood, E. C., Middlebrook, A. M., Kolb, C. E., Baltensperger, U., and Worsnop, D. R.: Evolution of Organic Aerosols in the Atmosphere, Science, 326, 1525-1529, doi:10.1126/science.1180353, 2009.
Jin, S., Huang, P., Park, J., Yoo, J. Y., and Breuer, K. S.: Nearsurface velocimetry using evanescent wave illumination, Exp. Fluids, 37, 825-833, doi:10.1007/s00348-004-0870-7, 2004.

Joly, L., Ybert, C., and Bocquet, L.: Probing the nanohydrodynamics at liquid-solid interfaces using thermal motion, Phys. Rev. Lett., 96, 046101, doi:10.1103/Physrevlett.96.046101, 2006.

Joseph, P. and Tabeling, P.: Direct measurement of the apparent slip length, Phys. Rev. E., 71, 035303, doi:10.1103/Physreve.71.035303, 2005.

Kang, E., Root, M. J., Toohey, D. W., and Brune, W. H.: Introducing the concept of Potential Aerosol Mass (PAM), Atmos. Chem. Phys., 7, 5727-5744, doi:10.5194/acp-7-5727-2007, 2007.

Kidd, C., Perraud, V., Wingen, L. M., and Finlayson-Pitts, B. J.: Integrating phase and composition of secondary organic aerosol from the ozonolysis of $\alpha$-pinene, P. Natl. Acad. Sci. USA, 111, 7552-7557, doi:10.1073/pnas.1322558111, 2014.

Kleindienst, T. E., Lewandowski, M., Offenberg, J. H., Jaoui, M., and Edney, E. O.: The formation of secondary organic aerosol from the isoprene $+\mathrm{OH}$ reaction in the absence of $\mathrm{NO}_{x}$, Atmos. Chem. Phys., 9, 6541-6558, doi:10.5194/acp-9-6541-2009, 2009.

Knopf, D. A.: Thermodynamic properties and nucleation processes of upper tropospheric and lower stratospheric aerosol particles, Diss. ETH No. 15103, Zurich, Switzerland, 2003.

Koop, T., Bookhold, J., Shiraiwa, M., and Pöschl, U.: Glass transition and phase state of organic compounds: dependency on molecular properties and implications for secondary organic aerosols in the atmosphere, Phys. Chem. Chem. Phys., 13, 19238-19255, doi:10.1039/C1cp22617g, 2011.

Kuwata, M., Chen, Q., and Martin, S. T.: Cloud condensation nuclei $(\mathrm{CCN})$ activity and oxygen-to-carbon elemental ratios following thermodenuder treatment of organic particles grown by $\alpha$ pinene ozonolysis, Phys. Chem. Chem. Phys., 13, 14571-14583, doi:10.1039/C1cp20253g, 2011.

Lambe, A. T., Ahern, A. T., Williams, L. R., Slowik, J. G., Wong, J. P. S., Abbatt, J. P. D., Brune, W. H., Ng, N. L., Wright, J. P., Croasdale, D. R., Worsnop, D. R., Davidovits, P., and Onasch, T. B.: Characterization of aerosol photooxidation flow reactors: heterogeneous oxidation, secondary organic aerosol formation and cloud condensation nuclei activity measurements, Atmos. Meas. Tech., 4, 445-461, doi:10.5194/amt-4-445-2011, 2011a.

Lambe, A. T., Onasch, T. B., Massoli, P., Croasdale, D. R., Wright, J. P., Ahern, A. T., Williams, L. R., Worsnop, D. R., Brune, W. H., and Davidovits, P.: Laboratory studies of the chemical composition and cloud condensation nuclei $(\mathrm{CCN})$ activity of secondary organic aerosol (SOA) and oxidized primary organic aerosol (OPOA), Atmos. Chem. Phys., 11, 8913-8928, doi:10.5194/acp11-8913-2011, 2011b.

Lambe, A. T., Chhabra, P. S., Onasch, T. B., Brune, W. H., Hunter, J. F., Kroll, J. H., Cummings, M. J., Brogan, J. F., Parmar, Y., Worsnop, D. R., Kolb, C. E., and Davidovits, P.: Effect of oxidant concentration, exposure time, and seed particles on secondary organic aerosol chemical composition and yield, Atmos. Chem. Phys., 15, 3063-3075, doi:10.5194/acp-15-3063-2015, 2015.

Li, L., Mo, J. W., and Li, Z. L.: Flow and slip transition in nanochannels, Phys. Rev. E., 90, 033003, doi:10.1103/Physreve.90.033003, 2014.

Liu, P. F., Zhang, Y., and Martin, S. T.: Complex Refractive Indices of Thin Films of Secondary Organic Materials by Spectroscopic 
Ellipsometry from 220 to $1200 \mathrm{~nm}$, Environ. Sci. Technol., 47, 13594-13601, doi:10.1021/Es403411e, 2013.

Liu, P. F., Abdelmalki, N., Hung, H.-M., Wang, Y., Brune, W. H., and Martin, S. T.: Ultraviolet and visible complex refractive indices of secondary organic material produced by photooxidation of the aromatic compounds toluene and $m$ xylene, Atmos. Chem. Phys., 15, 1435-1446, doi:10.5194/acp-15-1435-2015, 2015.

Martin, S. T.: Phase transitions of aqueous atmospheric particles, Chem. Rev., 100, 3403-3453, doi:10.1021/Cr990034t, 2000.

Martin, S. T., Andreae, M. O., Althausen, D., Artaxo, P., Baars, H., Borrmann, S., Chen, Q., Farmer, D. K., Guenther, A., Gunthe, S. S., Jimenez, J. L., Karl, T., Longo, K., Manzi, A., Müller, T., Pauliquevis, T., Petters, M. D., Prenni, A. J., Pöschl, U., Rizzo, L. V., Schneider, J., Smith, J. N., Swietlicki, E., Tota, J., Wang, J., Wiedensohler, A., and Zorn, S. R.: An overview of the Amazonian Aerosol Characterization Experiment 2008 (AMAZE08), Atmos. Chem. Phys., 10, 11415-11438, doi:10.5194/acp10-11415-2010, 2010a.

Martin, S. T., Andreae, M. O., Artaxo, P., Baumgardner, D., Chen, Q., Goldstein, A. H., Guenther, A., Heald, C. L., Mayol-Bracero, O. L., McMurry, P. H., Pauliquevis, T., Pöschl, U., Prather, K. A., Roberts, G. C., Saleska, S. R., Dias, M. A. S., Spracklen, D. V., Swietlicki, E., and Trebs, I.: Sources and Properties of Amazonian Aerosol Particles, Rev. Geophys., 48, Rg2002, doi:10.1029/2008rg000280, 2010b.

Murray, B. J., Wilson, T. W., Dobbie, S., Cui, Z. Q., Al-Jumur, S. M. R. K., Mohler, O., Schnaiter, M., Wagner, R., Benz, S., Niemand, M., Saathoff, H., Ebert, V., Wagner, S., and Karcher, B.: Heterogeneous nucleation of ice particles on glassy aerosols under cirrus conditions, Nat. Geosci., 3, 233-237, doi:10.1038/Ngeo817, 2010.

Murray, B. J., Haddrell, A. E., Peppe, S., Davies, J. F., Reid, J. P., O'Sullivan, D., Price, H. C., Kumar, R., Saunders, R. W., Plane, J. M. C., Umo, N. S., and Wilson, T. W.: Glass formation and unusual hygroscopic growth of iodic acid solution droplets with relevance for iodine mediated particle formation in the marine boundary layer, Atmos. Chem. Phys., 12, 8575-8587, doi:10.5194/acp-12-8575-2012, 2012.

Nakao, S., Tang, P., Tang, X. C., Clark, C. H., Qi, L., Seo, E., Asa-Awuku, A., and Cocker, D.: Density and elemental ratios of secondary organic aerosol: Application of a density prediction method, Atmos. Environ., 68, 273-277, doi:10.1016/j.atmosenv.2012.11.006, 2013.

Neto, C., Evans, D. R., Bonaccurso, E., Butt, H. J., and Craig, V. S. J.: Boundary slip in Newtonian liquids: a review of experimental studies, Rep. Prog. Phys., 68, 2859-2897, doi:10.1088/00344885/68/12/R05, 2005.

O'Brien, R. E., Neu, A., Epstein, S. A., MacMillan, A. C., Wang, B. B., Kelly, S. T., Nizkorodov, S. A., Laskin, A., Moffet, R. C., and Gilles, M. K.: Physical properties of ambient and laboratorygenerated secondary organic aerosol, Geophys. Res. Lett., 41, 4347-4353, doi:10.1002/2014gl060219, 2014.

Offenberg, J. H., Lewandowski, M., Jaoui, M., and Kleindienst, T. E.: Contributions of Biogenic and Anthropogenic Hydrocarbons to Secondary Organic Aerosol during 2006 in Research Triangle Park, NC, Aerosol Air. Qual. Res., 11, 99-U15, doi:10.4209/aaqr.2010.11.0102, 2011.

Pajunoja, A., Malila, J., Hao, L. Q., Joutsensaari, J., Lehtinen, K. E. J., and Virtanen, A.: Estimating the Viscosity Range of SOA
Particles Based on Their Coalescence Time, Aerosol. Sci. Tech., 48, I-Iv, doi:10.1080/02786826.2013.870325, 2014.

Pant, A., Parsons, M. T., and Bertram, A. K.: Crystallization of aqueous ammonium sulfate particles internally mixed with soot and kaolinite: Crystallization relative humidities and nucleation rates, J. Phys. Chem. A., 110, 8701-8709, doi:10.1021/Jp060985s, 2006.

Perraud, V., Bruns, E. A., Ezell, M. J., Johnson, S. N., Yu, Y., Alexander, M. L., Zelenyuk, A., Imre, D., Chang, W. L., Dabdub, D., Pankow, J. F., and Finlayson-Pitts, B. J.: Nonequilibrium atmospheric secondary organic aerosol formation and growth, P. Natl. Acad. Sci. USA, 109, 2836-2841, doi:10.1073/pnas.1119909109, 2012.

Pfrang, C., Shiraiwa, M., and Pöschl, U.: Chemical ageing and transformation of diffusivity in semi-solid multi-component organic aerosol particles, Atmos. Chem. Phys., 11, 7343-7354, doi:10.5194/acp-11-7343-2011, 2011.

Pöhlker, C., Wiedemann, K. T., Sinha, B., Shiraiwa, M., Gunthe, S. S., Smith, M., Su, H., Artaxo, P., Chen, Q., Cheng, Y. F., Elbert, W., Gilles, M. K., Kilcoyne, A. L. D., Moffet, R. C., Weigand, M., Martin, S. T., Pöschl, U., and Andreae, M. O.: Biogenic Potassium Salt Particles as Seeds for Secondary Organic Aerosol in the Amazon, Science, 337, 10751078, doi:10.1126/science.1223264, 2012.

Pöschl, U., Martin, S. T., Sinha, B., Chen, Q., Gunthe, S. S., Huffman, J. A., Borrmann, S., Farmer, D. K., Garland, R. M., Helas, G., Jimenez, J. L., King, S. M., Manzi, A., Mikhailov, E., Pauliquevis, T., Petters, M. D., Prenni, A. J., Roldin, P., Rose, D., Schneider, J., Su, H., Zorn, S. R., Artaxo, P., and Andreae, M. O.: Rainforest Aerosols as Biogenic Nuclei of Clouds and Precipitation in the Amazon, Science, 329, 15131516, doi:10.1126/science.1191056, 2010.

Power, R. M., Simpson, S. H., Reid, J. P., and Hudson, A. J.: The transition from liquid to solid-like behaviour in ultrahigh viscosity aerosol particles, Chem. Sci., 4, 2597-2604, doi:10.1039/C3sc50682g, 2013.

Reist, P.: Aerosol Science and Technology, McGraw-Hill Professional, New York, NY, USA, 2 Edn., 1992.

Renbaum-Wolff, L., Grayson, J. W., Bateman, A. P., Kuwata, M., Sellier, M., Murray, B. J., Shilling, J. E., Martin, S. T., and Bertram, A. K.: Viscosity of $\alpha$-pinene secondary organic material and implications for particle growth and reactivity, P. Natl. Acad. Sci. USA, 110, 8014-8019, doi:10.1073/pnas.1219548110, 2013a.

Renbaum-Wolff, L., Grayson, J. W., and Bertram, A. K.: Technical Note: New methodology for measuring viscosities in small volumes characteristic of environmental chamber particle samples, Atmos. Chem. Phys., 13, 791-802, doi:10.5194/acp-13791-2013, 2013b.

Renbaum-Wolff, L., Song, M., Grayson, J. W., Zhang, Y., Liu, P. F., Geiger, F. M., Martin, S. T., and Bertram, A. K.: Phase miscibility in secondary organic particles produced from $\alpha$-pinene ozonolysis, manuscript in preparation, 2015.

Riipinen, I., Pierce, J. R., Yli-Juuti, T., Nieminen, T., Häkkinen, S., Ehn, M., Junninen, H., Lehtipalo, K., Petäjä, T., Slowik, J., Chang, R., Shantz, N. C., Abbatt, J., Leaitch, W. R., Kerminen, V.-M., Worsnop, D. R., Pandis, S. N., Donahue, N. M., and Kulmala, M.: Organic condensation: a vital link connecting aerosol formation to cloud condensation nuclei $(\mathrm{CCN})$ concentrations, 
Atmos. Chem. Phys., 11, 3865-3878, doi:10.5194/acp-11-38652011, 2011.

Riipinen, I., Yli-Juuti, T., Pierce, J. R., Petaja, T., Worsnop, D. R., Kulmala, M., and Donahue, N. M.: The contribution of organics to atmospheric nanoparticle growth, Nat. Geosci., 5, 453-458, doi:10.1038/Ngeo1499, 2012.

Robinson, E. S., Saleh, R., and Donahue, N. M.: Organic Aerosol Mixing Observed by Single-Particle Mass Spectrometry, J. Phys. Chem. A., 117, 13935-13945, doi:10.1021/Jp405789t, 2013.

Robinson, N. H., Hamilton, J. F., Allan, J. D., Langford, B., Oram, D. E., Chen, Q., Docherty, K., Farmer, D. K., Jimenez, J. L., Ward, M. W., Hewitt, C. N., Barley, M. H., Jenkin, M. E., Rickard, A. R., Martin, S. T., McFiggans, G., and Coe, H.: Evidence for a significant proportion of Secondary Organic Aerosol from isoprene above a maritime tropical forest, Atmos. Chem. Phys., 11, 1039-1050, doi:10.5194/acp-11-1039-2011, 2011.

Saukko, E., Lambe, A. T., Massoli, P., Koop, T., Wright, J. P., Croasdale, D. R., Pedernera, D. A., Onasch, T. B., Laaksonen, A., Davidovits, P., Worsnop, D. R., and Virtanen, A.: Humiditydependent phase state of SOA particles from biogenic and anthropogenic precursors, Atmos. Chem. Phys., 12, 7517-7529, doi:10.5194/acp-12-7517-2012, 2012.

Schnell, E.: Slippage of Water over Nonwettable Surfaces, J. Appl. Phys., 27, 1149-1152, doi:10.1063/1.1722220, 1956.

Shiraiwa, M. and Seinfeld, J. H.: Equilibration timescale of atmospheric secondary organic aerosol partitioning, Geophys. Res. Lett., 39, L24801, doi:10.1029/2012g1054008, 2012.

Shiraiwa, M., Ammann, M., Koop, T., and Pöschl, U.: Gas uptake and chemical aging of semisolid organic aerosol particles, P. Natl. Acad. Sci. USA, 108, 11003-11008, doi:10.1073/pnas.1103045108, 2011.

Shiraiwa, M., Zuend, A., Bertram, A. K., and Seinfeld, J. H.: Gasparticle partitioning of atmospheric aerosols: interplay of physical state, non-ideal mixing and morphology, Phys. Chem. Chem. Phys., 15, 11441-11453, doi:10.1039/C3cp51595h, 2013.

Song, M. J., Marcolli, C., Krieger, U. K., Lienhard, D. M., and Peter, T.: Morphologies of mixed organic/inorganic/aqueous aerosol droplets, Faraday Discuss., 165, 289-316, doi:10.1039/C3fd00049d, 2013.

Tretheway, D. C. and Meinhart, C. D.: Apparent fluid slip at hydrophobic microchannel walls, Phys. Fluids, 14, L9-L12, doi:10.1063/1.1432696, 2002.

Tsigaridis, K. and Kanakidou, M.: Secondary organic aerosol importance in the future atmosphere, Atmos. Environ., 41, 46824692, doi:10.1016/j.atmosenv.2007.03.045, 2007.
Virtanen, A., Joutsensaari, J., Koop, T., Kannosto, J., Yli-Pirila, P., Leskinen, J., Makela, J. M., Holopainen, J. K., Pöschl, U., Kulmala, M., Worsnop, D. R., and Laaksonen, A.: An amorphous solid state of biogenic secondary organic aerosol particles, Nature, 467, 824-827, doi:10.1038/nature09455, 2010.

Wang, B. B., Lambe, A. T., Massoli, P., Onasch, T. B., Davidovits, P., Worsnop, D. R., and Knopf, D. A.: The deposition ice nucleation and immersion freezing potential of amorphous secondary organic aerosol: Pathways for ice and mixedphase cloud formation, J. Geophys. Res.-Atmos., 117, D16209, doi:10.1029/2012jd018063, 2012.

Wang, B., O’Brien, R. Kelly, S. T., Shilling, J. E., Moffet, R. C. Gilles, M. K., and Laskin, A.: Reactivity of Liquid and Semisolid Secondary Organic Carbon with Chloride and Nitrate in Atmospheric Aerosols, J. Phys. Chem. A., doi:10.1021/jp510336q, 2014.

Watanabe, K., Udagawa, Y., and Udagawa, H.: Drag reduction of Newtonian fluid in a circular pipe with a highly water-repellent wall, J. Fluid Mech., 381, 225-238, doi:10.1017/S0022112098003747, 1999.

Zelenyuk, A., Imre, D., Beranek, J., Abramson, E., Wilson, J., and Shrivastava, M.: Synergy between Secondary Organic Aerosols and Long-Range Transport of Polycyclic Aromatic Hydrocarbons, Environ. Sci. Technol., 46, 12459-12466, doi:10.1021/Es302743z, 2012.

Zhang, Q., Jimenez, J. L., Canagaratna, M. R., Allan, J. D., Coe, H., Ulbrich, I., Alfarra, M. R., Takami, A., Middlebrook, A. M., Sun, Y. L., Dzepina, K., Dunlea, E., Docherty, K., DeCarlo, P. F., Salcedo, D., Onasch, T., Jayne, J. T., Miyoshi, T., Shimono, A., Hatakeyama, S., Takegawa, N., Kondo, Y., Schneider, J., Drewnick, F., Borrmann, S., Weimer, S., Demerjian, K., Williams, P., Bower, K., Bahreini, R., Cottrell, L., Griffin, R. J., Rautiainen, J., Sun, J. Y., Zhang, Y. M., and Worsnop, D. R.: Ubiquity and dominance of oxygenated species in organic aerosols in anthropogenically-influenced Northern Hemisphere midlatitudes, Geophys. Res. Lett., 34, L13801, doi:10.1029/2007g1029979, 2007.

Zhou, S. M., Shiraiwa, M., McWhinney, R. D., Pöschl, U., and Abbatt, J. P. D.: Kinetic limitations in gas-particle reactions arising from slow diffusion in secondary organic aerosol, Faraday Discuss., 165, 391-406, doi:10.1039/C3fd00030c, 2013.

Zhu, L. W., Neto, C., and Attard, P.: Reliable Measurements of Interfacial Slip by Colloid Probe Atomic Force Microscopy. III. Shear-Rate-Dependent Slip, Langmuir, 28, 3465-3473, doi:10.1021/La204566h, 2012.

Zobrist, B., Marcolli, C., Pedernera, D. A., and Koop, T.: Do atmospheric aerosols form glasses?, Atmos. Chem. Phys., 8, 52215244, doi:10.5194/acp-8-5221-2008, 2008. 